\title{
An Economic Analysis of the Guaranty Contract
}

\author{
Avery Wiener Katz†
}

\begin{abstract}
Guaranty arrangements, in which one person stands as surety for a second person's obligation to a third, are ubiquitous in commercial transactions and in commercial law. In recent years, however, scholarly attention to the topic has been scant; and no one has systematically analyzed this body of law and practice from an economic policy perspective. Accordingly, this Article attempts to outline the basic economic logic underlying the guaranty relationship, and applies the results to a variety of specific issues in government policy and private planning. It poses and answers three main questions: First, why would a creditor prefer to make a guaranteed loan rather than an unguaranteed one? The answer is not as obvious as might first appear, given that market competition over credit terms tends to adjust the interest rate paid by an individual borrower to reflect the specific default risk that he presents. Second, given that they bear the residual risk of debtor default, why would guarantors prefer to guarantee loans rather than make loans directly, thus forgoing the opportunity to earn interest payments that could help to compensate for the risk they bear? Third, even if it is efficient for one creditor to provide funds and another to provide insurance against default, why would the parties prefer to implement this arrangement through the triangular form of a guaranty, instead of simply having the former creditor lend to the latter and the latter lend to the ultimate borrower?
\end{abstract}

\section{INTRODUCTION}

Guaranty arrangements, in which one person stands as surety for a second person's obligation to a third, are ubiquitous in commercial transactions and in commercial law. They are probably as common as personal property security or real mortgages, and surely of wider application. The interrelated rights and duties arising out of guaranties and analogous devices comprise a substantial part of several distinct bodies of law, including secured transactions, negotiable instruments, letters of credit, and contractual assignments. And the practical and legal distinctions among guaranties and alternate transactional forms are relevant to a wide array of regulatory regimes, including tax, banking, insurance, and securities law. Indeed, up until the

$\dagger$ Professor of Law, Georgetown University Law Center. I am grateful to Allan Axelrod, Robert Barsky, Lisa Bernstein, Jim Bowers, Merritt Fox, Michal Gal, Victor Goldberg, Michael Heller, Claire Hill, Wendy Wiener Katz, Michael Klausner, Kyle Logue, Ronald Mann, Scott Masten, Warren Schwartz, William Vukowich, David Weisbach, James J. White, and seminar participants at the University of Michigan, Columbia, and University of Pennsylvania law schools and at the American Law and Economics Association for helpful comments; to Aviva Kazdan, Andrew Niebler, David Prohofsky, and John Sheckler for excellent research assistance; and to the Dean's Research Fund at Georgetown University Law Center and the John M. Olin Program at Columbia Law School for financial support. 
1950s, the standard law school curriculum included a required course on suretyships. ${ }^{1}$

In recent years, however, the law of guaranties has languished in a scholarly backwater. Lawyers specializing in the area lament that the field has "fallen between the cracks," and that bench, bar, and academy are all ignorant of its content and practical importance. ${ }^{3}$ From a purely doctrinal viewpoint, it must be said, this situation is beginning to change. Three major new reformulations of guaranty law-the recent revisions of Articles 3 and 5 of the Uniform Commercial Code ${ }^{4}$ and the just released Restatement (Third) of Suretyship and Guaranty ${ }^{5}$-have been adopted in the last few years. Practicing lawyers will be forced to learn or re-learn this field of law, at the risk of malpractice liability. But despite this flourishing of doctrinal reform, and despite the commercial importance of the transactions thus governed, there has been no systematic theoretical treatment of the subject from an economic perspective. This omission is especially noteworthy, moreover, given the substantial body of scholarship in recent years in the cognate fields of secured transactions and bankruptcy. While economists and legal scholars have written on such topics as the economic function of secured debt, ${ }^{6}$ bankruptcy law's function in providing incentives for creditors and debtors to

' See Neil B. Cohen, Striking the Balance: The Evolving Nature of Suretyship Defenses, 34 Wm \& Mary L Rev 1025, 1025 (1993) (noting that suretyships are no longer part of the law school curriculum). See also Michael L. Closen, Teaching with Recent Decisions: A Survey of Past and Present Practices, 11 Fla St U L Rev 289, 312-38 (1983) (Author's representative sample of two-hundred eighty-two legal casebooks published between 1875 and 1982 revealed that suretyship was the subject of three of the sixteen earliest casebooks in the sample, five of the fifty-two casebooks published before 1945, and none of twohundred thirty casebooks published after 1945. The most recent suretyship book in Closen's sample was published in 1942.).

2 Donald J. Rapson, History and Background of the Restatement of Suretyship, $34 \mathrm{Wm}$ \& Mary L Rev 989, 1011 (1993).

3 Id at 1012. See also Cohen, $34 \mathrm{Wm} \&$ Mary L Rev at 1025-26 (cited in note 1); Gerald T. McLaughlin, Standby Letters of Credit and Guaranties: An Exercise in Cartography, 34 Wm \& Mary L Rev 1139, 1139 (1993).

4 Articles 3 and 5 were revised in 1990 and 1995. See Douglas G. Baird, Theodore Eisenberg, and Thomas H. Jackson, eds, Commercial and Debtor-Creditor Law: Selected Statutes iii (Foundation 1998).

${ }^{5}$ Restatement of the Law (Third) of Suretyship and Guaranty (ALI 1996) ("Restatement $\left.3 \mathrm{~d}^{\prime}\right)$. The new Restatement is intended to supersede its most immediate predecessor, Restatement of the Law of Security, Division II (ALI 1941). It also covers certain topics treated in the Restatement of the Law (Second) of Contracts (ALI 1973).

${ }^{6}$ See, for example, Alan Schwartz, Security Interests and Bankruptcy Priorities: A Review of Current Theories, $10 \mathrm{~J}$ Legal Stud 1 (1981); Robert E. Scott, A Relational Theory of Secured Financing, 86 Colum L Rev 901 (1986); Alan Schwartz, A Theory of Loan Priorities, 18 J Legal Stud 209 (1989); George G. Triantis, Secured Debt Under Conditions of Imperfect Information, $21 \mathrm{~J}$ Legal Stud 225 (1992). 
maximize the value of failing enterprises, ${ }^{7}$ and the incentive and notice problems created when creditors take nonpossessory interests in a debtor's property, ${ }^{8}$ no one has analyzed the simple and widespread guaranty contract, for which all of these other devices are economic substitutes.

This Article outlines the basic economic logic of the guaranty relationship-its underlying costs and benefits and the key features that distinguish it from alternative financial arrangements. This basic logic is simple, but it has applications across a broad array of problems faced by commercial and business lawyers. These problems include determining the optimal scope of suretyship rights and defenses, reconciling the treatment of guaranties across various bodies of commercial law, and helping tax and regulatory agencies to evaluate transactions based on substance rather than form.

More importantly, however, a clear account of the economics of guaranties is essential to explaining why contracting parties might-and when they should - enter into guaranty relationships and the specific rights and duties that arise from them. Understanding the economics of guaranties is critical to designing an intelligent regulatory regime for debtor-creditor relations, but it is even more important for the lawyer engaged in advising clients how to structure their financial affairs. In most situations, clients have some leeway to choose whether to pursue their goals either through guaranties or through alternative devices; in those cases in which they do decide to enter into guaranties, they typically are free to contract out of the various default rules that suretyship and related fields of law provide. ${ }^{9}$ A good commercial lawyer, therefore, needs to understand the functional underpinnings of a transaction in order to help plan it-and in commercial settings, these underpinnings are economic.

Such a functional perspective is relevant in both private and public settings. For example, many government policies are in-

7 See, for example, Thomas H. Jackson, The Logic and Limits of Bankruptcy Law 15192 (Harvard 1986); F.H. Buckley, The Bankruptcy Priority Puzzle, 72 Va L Rev 1393 (1986); Douglas G. Baird and Randal C. Picker, A Simple Noncooperative Bargaining Model of Corporate Reorganizations, $20 \mathrm{~J}$ Legal Stud 311 (1991); Douglas G. Baird, Revisiting Auctions in Chapter 11, $36 \mathrm{~J}$ L \& Econ 633 (1993).

${ }^{8}$ See, for example, Douglas G. Baird, Notice Filing and the Problem of Ostensible Ownership, 12 J Legal Stud 53 (1983); Douglas G. Baird and Thomas H. Jackson, Possession and Ownership: An Examination of the Scope of Article 9, 35 Stan L Rev 175 (1983).

- See, for example, Uniform Commercial Code § 1-102(3) (ALI 1995) (“UCC”) (providing that UCC rules may in general be varied by the parties' agreement, and that obligations of reasonableness, diligence, and good faith, while not disclaimable, can be given specific content through agreement); Restatement $3 \mathrm{~d} \S 6$ (cited in note 5) (All rules of suretyship law can be varied by the parties' agreement.). 
tended to assist debtors, both individual and institutional. These policies, which include federal student loans, government-backed home and farm mortgages, bailouts of private entities such as Chrysler or Lockheed, and international loan guaranties for foreign allies such as Israel or Mexico, are motivated by a variety of economic and political considerations. Whatever the goals of such programs, however, it is in the public interest that they be pursued through an efficient transactional form. To take just one example, in recent years federal support for education lending has shifted from a program of guaranteed student loans toward one of direct student loans, on the supposed rationale of greater administrative efficiency. ${ }^{10}$ The Clinton administration has favored yet a third alternative, subsidizing student loans through the income tax system. ${ }^{11}$ An economic analysis of guaranties is necessary to determine which of these arrangements is indeed most efficient.

Nonetheless, the arguments that follow may well be of greater utility to business lawyers designing individual transactions than to legislators, judges, or other regulators. In my view, this is a strength of the analysis rather than a weakness. As I have argued elsewhere, contemporary legal scholars-even those associated with the relatively market-oriented perspective of law and economics-have focused disproportionately on analyzing public policies and have addressed themselves primarily to government decisionmakers. ${ }^{12}$ Because private actors also care about efficiency and distribution in ordering their affairs, the theoretical insights of economics are at least as valuable to them as they are to public officials. Just as the citizens of the United States must decide whether their government should lend funds to the government of Mexico directly, guarantee loans made to Mexico by a third-party lender, or leave Mexico to its own financial devices, so must a commercial bank decide whether to demand that a credit applicant provide a co-signer or whether to issue a standby letter of credit for an existing customer seeking addi-

\footnotetext{
${ }^{10}$ For surveys and critiques of recent changes and proposed changes in federal policy toward student loans, see generally Evelyn Brody, Paying Back Your Country Through Income-Contingent Student Loans, 31 San Diego L Rev 449 (1994); Dennis Zimmerman and Barbara Miles, Substituting Direct Government Lending for Guaranteed Student Loans: How Budget Rules Distort Economic Decisionmaking, 47 Natl Tax J 773, 773-80 (1994); Barbara Miles and Dennis Zimmerman, Reducing Costs and Improving Efficiency in the Student Loan Program, 50 Natl Tax J 541, 541-48 (1997).

${ }^{11}$ See Brody, 31 San Diego L Rev at 453-54 (cited in note 10) (discussing President Clinton's support for the proposal and examining the optimal structure for incomecontingent repayment of student loans).

${ }^{12}$ See Avery Katz, Taking Private Ordering Seriously, 144 U Pa L Rev 1745, 1748 (1996).
} 
tional funds from another lender. The same set of functional economic issues apply whether one is making public or private policy.

In the succeeding sections of this Article, therefore, I lay out the basic economics of suretyships and guaranties. The Article poses three main questions. First, why would a creditor prefer to make a guaranteed loan rather than an unguaranteed one? The answer is not as obvious as it first might appear, given that market competition over credit terms tends to adjust the interest rate paid by an individual borrower to reflect the specific default risk that he or she presents. ${ }^{13}$ Second, since guarantors bear the residual risk of debtor default, why would they prefer to guarantee loans rather than make loans themselves, thus forgoing the opportunity to earn interest payments that could help compensate for the risk of default? Third, even if it is efficient for one lender to provide funds and another to provide insurance against the borrower's default, why would the parties prefer to accomplish such an arrangement through the three-corner form of a guaranty instead of simply having the former lend to the latter and the latter on-lend to the ultimate borrower?

In brief, the answers to these questions are as follows. First, and most straightforwardly, creditors should prefer to make guaranteed loans when, and only when, there is a potential guarantor who can monitor the debtor more cheaply than the creditor can. Monitoring in this regard should be understood broadly to include any and all activities that reduce the expected cost of nonpayment, including up-front investigation of the debtor's credit history and financial situation, supervision of the debtor and his project during the life of the loan, and enforcement, collection, and salvage in the event of default.

Second, the person who is the lowest-cost monitor will prefer to act as guarantor, rather than as primary lender, when, and only when, her cost of liquidity-that is, the transaction costs she must pay to convert her assets into an acceptable means of ready payment-is greater than that of potential third-party lenders. In essence, suretyship is an economic arrangement in which one party specializes in providing liquid funds and another specializes in providing informational monitoring, collection services, and insurance.

Third, and perhaps least obviously, guaranties are more efficient than on-lending or other forms of intermediation when, and

\footnotetext{
${ }^{23}$ See, for example, Schwartz, $10 \mathrm{~J}$ Legal Stud at 7-9 (cited in note 6) (demonstrating how this adjustment would work in an idealized market for secured credit).
} 
only when, the party who provides liquid funds attaches a higher value to the option to proceed directly against the ultimate borrower (in the event of default) than does the party who provides monitoring and collection services. And this will be the case either when the latter's comparative advantage is less than complete (for instance, if she is good at underwriting and monitoring, but less good at collection or salvage), or when there is a significant chance that the monitor herself will turn out to be insolvent or uncollectable.

To develop these ideas more fully, however, requires some groundwork. Thus, the next Section presents some background on the subject of guaranties. It sets out an array of typical situations involving guaranty relationships, outlines the various bodies of law that govern such situations, and summarizes the main questions and unresolved controversies that arise in those legal fields. Section II, which forms the heart of this Article, then compares the costs and benefits of guaranties with those of related transactional forms and discusses why (and when) contracting parties would-and should-prefer one type of transactional form to another. Section III applies this theoretical analysis to two questions of public policy and private planning: (1) how should the government operate when it wishes to subsidize borrowing, and (2) how should a commercial bank structure its risks and duties when it issues a standby letter of credit. The Conclusion summarizes the analysis and suggests some further applications to analogous problems in law, policy, and planning.

\section{THE LAW OF GUARANTIES AND SURETYSHIPS: A SENSE OF THE TERRAIN}

The number and variety of transactions that include or imply guaranty relationships are vast. In order to situate the problem in a business and policy context, this Section surveys a sample of such relationships and summarizes the legal issues that arise from them. Readers familiar with this background material or eager to get to the main theoretical points of the Article may wish to skip directly to the next Section. Even a brief perusal of the following examples, however, will help to convey the scope and practical relevance of the analysis to follow.

\section{A. The Standard Guaranty Relationship}

Guaranties and suretyships take many forms, but the essence of the relationship is a contract among three parties: a creditor (C) who is owed a duty, a debtor (D) who owes the duty, 
and a guarantor or surety (G) who promises to perform or pay damages on D's behalf. ${ }^{14}$ Depending on the context and the applicable body of law, however, these three parties are designated by different labels, as illustrated in Table 1 . In the terminology of the Third Restatement, for example, $\mathrm{C}$ is the "obligee," $\mathrm{D}$ the "primary obligor," and G the "secondary obligor." As this terminology suggests, ordinarily $D$ is expected to bear the burden of performance, and if $G$ is called upon to perform or pay in D's stead, it is ordinarily expected that $D$ will reimburse her if he is able. ${ }^{16}$ The arrangement can be achieved through a single contract or through multiple contracts; in the latter case, G may contract with $\mathrm{D}$ alone, with $\mathrm{C}$ alone, or with both. A guaranty may even be created without the knowledge of $D$ or $C$, though in this case the parties' rights and duties will be altered in order to protect the uninformed party. This simple model of the relationship between $C, D$, and $G$ is general enough to encompass a wide variety of business and policy contexts, as the following examples illustrate.

Table 1. Terminology of the Guaranty Relationship in Alternative Contexts.

\begin{tabular}{|l|l|l|l|}
\hline & \multicolumn{1}{|c|}{ C } & \multicolumn{1}{c|}{$\mathbf{D}$} & \multicolumn{1}{c|}{ G } \\
\hline $\begin{array}{l}\text { Restatement of } \\
\text { Suretyship }\end{array}$ & Obligee & Primary obligor & $\begin{array}{l}\text { Secondary } \\
\text { obligor }\end{array}$ \\
\hline $\begin{array}{l}\text { Negotiable } \\
\text { instrument }\end{array}$ & Holder & $\begin{array}{l}\text { Accommodated } \\
\text { party }\end{array}$ & $\begin{array}{l}\text { Accommodation } \\
\text { party }\end{array}$ \\
\hline $\begin{array}{l}\text { Sale of } \\
\text { accounts }\end{array}$ & Assignee & Account debtor & Assignor \\
\hline $\begin{array}{l}\text { Letter of } \\
\text { credit }\end{array}$ & Beneficiary & Applicant & Issuer \\
\hline $\begin{array}{l}\text { Lease } \\
\text { assumption }\end{array}$ & Landlord & Subtenant & Primary tenant \\
\hline
\end{tabular}

\footnotetext{
14 Traditionally, a "suretyship" describes a relationship in which the guarantor and debtor are jointly and severally liable for the underlying obligation, while under a "guaranty" the debtor's actual default is a condition precedent to the guarantor's obligation to perform. See Restatement $3 d \S 15$ (cited in note 5). Because of variations among the individual provisions of guaranty and suretyship contracts, however, the two terms overlap substantially in actual practice. Id $\S 1$ comment $c$ and $\$ 15$ comment b. For this reason, I will use the terms interchangeably in this Article, except where the question of a condition precedent to guarantor liability is specifically relevant to the discussion.

${ }^{25} \mathrm{Id} \S \mathrm{I}(\mathrm{a})$.

${ }^{16}$ Id $\S 22$. In order to avoid ambiguity when discussing generic guaranty transactions, I adopt the convention of referring to debtors and primary obligors, with male pronouns, guarantors and sureties with female pronouns, and creditors with neuter pronouns.
} 
1. Intrafamilial guarantees.

$\mathrm{D}$, a college senior who is about to graduate and take his first job, wants to buy a car. He has enough money for the down payment, but has not yet established a credit history. His only borrowing experience consists of student loans, which will not become due for six months and which he has not yet begun to repay. Accordingly, only finance companies that specialize in lending to risky debtors will be willing to deal with $\mathrm{D}$ on his own, and those companies' interest rates are substantially higher than the market average (and the rates available to someone with a longer credit history). If $\mathrm{D}$ can find someone with an established credit record to guarantee his loan, however, he will be eligible for more conventional and cheaper financing from $\mathrm{C}$, a local bank. $\mathrm{D}$ arranges with his mother, $\mathrm{G}$, to provide such a guaranty by cosigning his loan application and by co-signing the promissory note that $\mathrm{D}$ must execute in C's favor before receiving funds.

2. Intercorporate guaranties.

D, a limited liability corporation, needs financing to modernize its capital equipment. C, one of D's longstanding suppliers, is willing to lend $D$ the necessary funds, but is concerned about D's leveraged capital structure and relative lack of marketable assets. Accordingly, as a condition of the loan, $\mathrm{C}$ requests and obtains guaranties from D's parent company, G1, and from G1's sole shareholder, G2. In the event that D defaults, these guaranties allow $\mathrm{C}$ to access assets that ordinarily could not be reached without piercing the corporate veil, thus reducing C's risk and lowering the interest rate it will charge. ${ }^{17}$

3. Standby letters of credit.

D, a software design company, wishes to borrow funds for a new project from $C$, a commercial bank with whom it has not dealt previously. Because a regular loan would entail a new credit investigation and require $\mathbf{C}$ to familiarize itself with a new type of business, $\mathrm{C}$ would have to charge $\mathrm{D}$ more than the prime rate of interest. $\mathrm{C}$, however, will loan the funds to $\mathrm{D}$ at or below the prime rate if $D$ approaches $G$, a bank with whom it has a longstanding relationship, and obtains a standby letter of credit

\footnotetext{
${ }^{17}$ In the commercial setting, furthermore, it is common for such guaranties to be accompanied by other forms of lender protection. For example, both the underlying obligation and the guaranties might be secured by a purchase money security interest in the new equipment or other real or personal collateral.
} 
naming $\mathrm{C}$ as beneficiary. This letter of credit provides that if $\mathrm{C}$ presents $G$ with documents attesting that $D$ has defaulted on C's loan, $\mathrm{C}$ will be entitled to draw on the credit up to an agreed limit. In exchange for a fee proportional to the amount of the standby credit, $G$ issues the letter to $D$, who presents it to $C$ in exchange for the desired funds. ${ }^{18}$

4. Construction suretyships.

$\mathrm{D}$, a construction contractor, submits the lowest bid on a job to build a new school on a site owned by $\mathrm{C}$, a municipal school district. As a condition of awarding $\mathrm{D}$ the contract, however, $\mathrm{C}$ requires $\mathrm{D}$ to obtain a third-party surety bond. $\mathrm{D}$ purchases such a bond from G, a company specializing in providing such assurances. The bond obligates $G$ to complete the job if $D$ does not, and also obligates $G$ to pay all outstanding amounts owed to subcontractors and suppliers of materials, to remove any construction or mechanics' liens on the property at the conclusion of the project, and to pay any penal sums owed to $C$ under the original contract. The surety bond also provides that all funds that $\mathrm{C}$ may owe $\mathrm{D}$ under the contract will stand as collateral for any claims that $G$ may acquire against $D$. Thus, if $G$ completes the job in D's stead, $G$, not $D$, will be entitled to receive the contract price. ${ }^{19}$

\section{Recourse assignments of accounts, chattel paper, or instruments.}

$G$, a dealer in consumer appliances, sells a refrigerator to D on credit. $\mathrm{G}$ then assigns her interest in D's account to $\mathrm{C}$, a factor (in other words, a company in the business of buying such accounts), in exchange for an immediate cash payment. The underlying consumer debt may also be secured by a security interest in the refrigerator, in which case the assigned contract is referred to as "chattel paper"; alternatively or additionally, the debt may be embodied in the form of a negotiable promissory note signed by $\mathrm{D}$

${ }^{18}$ The parties may, if they wish, dispense with any requirement of attesting documents; this is called a "demand" or "clean" letter of credit. See, for example, McLaughlin, $34 \mathrm{Wm} \&$ Mary L Rev at 1141-43 (cited in note 3); Bernard S. Wheble, "Problem Children"-Standby Letters of Credit and Simple First Demand Guarantees, 24 Ariz L Rev 301, 313 (1982); Dean Pawlowic, Standby Letters of Credit: Review and Update, 23 UCC L J 391, 399-400 (1991); Henry Harfield, Guaranties, Standby Letters of Credit, and Ugly Ducklings, 26 UCC L J 195, 198-99 (1994).

${ }_{19}^{19}$ Performance bonds are a typical provision in government contracts at the state and local level, and are required for all federal public works projects under the Miller Act, 40 USC $\S 270$ a(a) (1994). For a general discussion of surety bonds, see T. Scott Leo, The Construction Contract Surety and Some Suretyship Defenses, 34 Wm \& Mary L Rev 1225, $1233-40$ (1993). 
as maker and indorsed by $\mathrm{G}$ over to $\mathrm{C}$. In any of these cases, however, the amount of cash that $C$ pays $G$ for the account, chattel paper, or instrument will be less than its face value. This discount reflects the facts that payment will be delayed and that the factor must service the account and incur costs of collection. The assignment, however, is on a recourse basis: to the extent that the accounts are uncollectible (or, more generally, to the extent that the shortfall in collections exceeds some agreed amount), $G$ must refund C's payment and retake possession of the bad account, effectively rendering $G$ a guarantor of the underlying debt. A similar analysis applies to assignments of contractual rights more generally, so long as the assignment is with recourse. ${ }^{20}$

6. Joint and several liability.

A single transaction may involve multiple guarantors and multiple debtors, with some parties acting as debtors for some obligations and as guarantors for others. ${ }^{21}$ To illustrate, suppose two law students, A and B, decide to lease an apartment together. The lease contract makes each tenant jointly and severally liable for the entire monthly rent of $\$ 1,000$. The students agree between themselves, however, that $\mathrm{A}$ will take the larger bedroom and pay $\$ 600$ per month while $B$ will take the smaller bedroom and pay $\$ 400$ per month. These two agreements-the lease contract and the side agreement between $\mathrm{A}$ and $\mathrm{B}$-together render $\mathrm{A}$ and $\mathrm{B}$ both debtors and guarantors with respect to their landlord. As to the $\$ 600$ rent on the larger bedroom, $\mathrm{A}$ is debtor and $\mathrm{B}$ is guarantor; as to the $\$ 400$ rent on the smaller bedroom, $B$ is debtor and $A$ is guarantor. This is so whether or not the landlord knows of the students' side agreement; indeed, one advantage of such an arrangement is that the landlord does not need to keep track of how its tenants apportion the lease obligations among themselves.

\section{Government-sponsored enterprises.}

A number of U.S. government-chartered institutions participate directly in credit markets, in some instances as direct lenders and in others as guarantors of loans extended by private lenders. ${ }^{22}$ Such institutions include the Federal National Mort-

\footnotetext{
${ }^{20}$ For examples, see D. Benjamin Beard, Suretyship on the Fringe: Suretyship by Operation of Law and by Analogy, 34 Wm \& Mary L Rev 1157, 1165-93 (1993).

${ }^{21}$ For a description of the rights and duties that multiple debtors and guarantors may owe each other in a single transaction, see Restatement 3d $\$ \S 52-61$ (cited in note 5) ("Multiple Secondary Obligors").

${ }^{2}$ See Report of the Secretary of the Treasury on Government Sponsored Enterprises
} 
gage Association ("Fannie Mae"), the Federal Home Loan Mortgage Corporation ("Freddie Mac"), the Farm Credit System, and the Student Loan Marketing Association ("Sallie Mae"). While these entities technically are not governmental agencies, and thus have no formal legal claim on assets of the federal government, historically all were created and periodically infused with federal funds, and they continue to be subject to substantial federal regulation. Due to their political popularity and their importance to the national economy, if any one of these institutions were in danger of failure, Congress would come under substantial pressure to rescue it from default. In an informal political sense, then, U.S. taxpayers stand as the ultimate guarantors of debts owed by these institutions; for this reason, investors are willing to lend to these entities at lower interest rates than they would demand from a comparable private borrower..$^{23}$

\section{Guaranties between independent national sovereigns.}

On several recent occasions, the U.S. government has assisted allied countries in obtaining private sector financing for their national debts. Such assistance operates both as a form of foreign aid and as a tool for pursuing other foreign policy objectives. For instance, in the fall of 1992, the U.S. guaranteed $\$ 10$ billion in loans to the Israeli government for the purpose of financing housing for emigrants from the former Soviet Union; similarly, in January 1995, the U.S. guaranteed $\$ 40$ billion in loans to Mexico as part of an international aid package designed to prevent the Mexican government from defaulting on existing obligations after market pressures forced it to devalue the peso. In both instances, the loan guaranties were the subject of substantial public controversy, on both fiscal and foreign policy grounds. ${ }^{24}$ Similarly, the U.S. government has routinely guaranteed smaller loans to foreign governments for specific purchases

(1990); Report of the Secretary of the Treasury on Government-Sponsored Enterprises (1991) ("1991 Report"). Both reports discuss the potential financial problems raised by these entities' operations and recommend associated reforms.

${ }^{23} 1991$ Report at 1-2 (cited in note 22).

${ }^{24}$ See, for example, John Quigley, Loan Guarantees, Israeli Settlements, and Middle East Peace, 25 Vand J Transnatl L 547, 568-72 (1992) (arguing that such loan guaranties, as well as other forms of U.S. aid to Israel, facilitate and may constitute violations of international law and diminish prospects for peace in the Middle East); James D. Humphrey II, Note, Foreign Affairs Powers and "The First Crisis of the 21st Century": Congressional vs. Executive Authority and the Stabilization Plan for Mexico, 17 Mich J Intl L 181, 201-10 (1995) (describing and analyzing the political contest between the President and Congress over Mexican guaranties). 
such as arms sales, both for foreign policy reasons and to promote the commercial interests of American exporters. ${ }^{25}$

\section{B. The Law Governing Guaranties}

Because a guaranty relationship can be achieved through a variety of contractual devices, the precise body of law that governs the relationship will depend on the particular device used. Generally, the parties' relationship will be governed by the common law of contracts and suretyship, the latter of which has recently been recatalogued by the Third Restatement. If a guarantor $(G)$ acquires her status by making or indorsing a negotiable instrument, however, the parties' relationship will be governed first by Article 3 of the Uniform Commercial Code ("UCC"), which provides special rules for "accommodation parties," and next by any common law rules that the UCC does not specifically displace. ${ }^{26}$ If the guaranty takes the form of a standby letter of credit, which is routine when the guarantor is a commercial bank, the relationship is governed in part by Article 5 of the UCC, in part by the common law, and-if the transaction has an international element-in part by the International Chamber of Commerce's Uniform Customs and Practice for Documentary Credits. ${ }^{27}$ If the guarantor provides collateral to secure the underlying secondary obligation, or if the guaranty arises out of a sale or assignment of accounts, then UCC Article 9 governs the transaction. Finally, as indicated above, if the U.S. government or U.S.sponsored institutions guarantee a loan, then federal statutesand, ultimately, implicit political contracts among Congress, the executive branch, international actors, and American votersprovide the basis for liability. ${ }^{28}$

${ }^{25}$ See, for example, Jonathan E. Sanford, Foreign Debts to the U.S. Government: Recent Rescheduling and Forgiveness, 28 Geo Wash J Intl L \& Econ 345, 361-63 (1995).

${ }^{25}$ See UCC § 3-419 ("Tnstruments Signed for Accommodation"); UCC § 3-605 ("Discharge of Indorsers and Accommodation Parties"). These sections apply only if an indication of G's guaranty appears on the face of the instrument being guaranteed. In this case, $\mathrm{G}$ is an "accommodation party" and D an "accommodated party." "Off-the-paper" guaranties, conversely, are governed solely by the common law. See generally Neil B. Cohen, Suretyship Principles in the New Article 3: Clarifications and Substantive Changes, $42 \mathrm{Ala}$ $L$ Rev 595 (1991) (discussing general principles embodied in Article 3).

${ }^{27}$ See UCC § 5-103 ("Scope"); UCC § 5-108 ("Issuer Rights and Obligations"). For a survey of international law and practice in the area of letters of credit, see Boris Kozolchyk, Bank Guarantees and Letters of Credit: Time for a Return to the Fold, $11 \mathrm{U}$ Pa J Intl Bus L 1, 15-67 (1989); ICC Uniform Customs and Practice for Documentary Credits 19-24 (ICC 1993) ("Liabilities and Responsibilities"). The extent to which common law principles continue to govern letters of credit is a matter of dispute, as Section III.B discusses.

${ }^{28}$ The above survey is far from exhaustive. For instance, a guaranty relationship could also be covered by state and federal statutes regulating the sale of financial options, since 
Whatever body of law, commercial practice, or political understanding creates the guaranty, the functional issues are much the same. Guaranties are a response to potential moral hazard and adverse selection problems: they help protect creditors against some of the risks of debtor misbehavior or insolvency by shifting those risks to guarantors. In so doing, guaranties enlist the guarantor's efforts in reducing or managing those risks. As with any other insurance arrangement, however, guaranties themselves are subject to various types of moral hazard and adverse selection. Each party to the transaction can impose losses on the others by failing to take precautions or by withholding information. For example, guarantors have the power to hurt creditors (and debtors as well) by incautiously offering guaranties where the underlying financial situation does not warrant a loan, or by failing to monitor the debtor after money has been lent. Creditors may hurt guarantors (and debtors) by provoking debtors to default, by failing to collect from the debtor when possible, and by impairing the guarantor's ability to seek recourse from the debtor after the fact. Debtors can injure guarantors and creditors alike by taking excessive risks and making inadequate efforts to meet their primary obligations. Moreover, the very creation of a suretyship can itself raise incentive problems, particularly when one of the parties to the underlying primary contract had not anticipated that a three-corner relationship would arise. ${ }^{29}$

Because of these common functional problems, all bodies of formal guaranty law provide the three archetypical parties with various rights and duties that, on the whole, are designed to discourage opportunism and encourage all persons involved to take reasonable precautions against economic loss. All regimes of guaranty law provide a default rule giving $G$ a right of recourse against $D$ in the event $D$ does not perform his primary obligation and $\mathrm{G}$ has to make good on her guaranty.

one common way to provide the functional equivalent of a guaranty is for $\mathrm{G}$ to sell to $\mathrm{C}$ a put option that gives her the right to collect from $\mathbf{G}$. $C$ will subsequently wish to exercise the option if and only if the expected value of D's performance falls below the exercise price. If the debtor becomes insolvent, various state rules of debtor-creditor law including the law of fraudulent conveyances will govern; and if the debtor files for federal bankruptcy protection, a variety of Bankruptcy Code provisions will also apply-the most important of which deal with preferences and fraudulent conveyances.

${ }^{20}$ For instance, a creditor who privately and unilaterally arranges for a guaranty may substantially increase the debtor's cost of compliance under the primary contract, multiplying the number of persons to whom he owes duties of care or disclosure. Similar problems arise when a creditor transfers its interest in the debtor's account to a distant and unfamiliar assignee, or when a debtor delegates performance of contractual duties to an untested person with whom the creditor will nonetheless be obligated to make reasonable efforts to deal. 
The common law of suretyship, for example, protects this right of recourse in three ways. First, $G$ is entitled to the right of reimbursement for any funds she actually pays out, plus reasonable expenses..$^{30}$ Second, and alternatively, if G satisfies D's obligation to $\mathrm{C}$ in full, she is equitably subrogated to C's rights against $D .^{31}$ This subrogation right is valuable if $\mathrm{C}$ has some special status (such as that of holder in due course) that gives her immunity against claims and defenses that $D$ could otherwise raise (and specifically, that $D$ could raise against $G$ ). It is also useful if $C$ has priority over D's other creditors through a lien or other interest in specific property. Finally, G has a right to D's performance itself-that is, the right of exoneration. ${ }^{32}$ This last right is valuable because $G$ can assert it before her duty to pay anything out has arisen, and such early action may increase the chances that $D$ will still perform. Depending on the circumstances, the right of exoneration may entitle $G$ to receive specific performance from $D$, pursue an action against $D$ for creating insecurity along the lines of the right of adequate assurances under Section 2-609 of the UCC, or declare the contract in default..$^{33}$

Conversely, guaranty law provides a number of rules designed to protect guarantors against creditor action that materially increases guarantor risk. Thus, if the debtor's breach was occasioned by a countervailing breach by $\mathrm{C}$-as when a credit buyer of goods withholds payment after discovering that the goods are unmerchantable-the traditional common law rule permits $G$ to treat C's breach as a defense to her secondary liability to the same extent it would provide a defense to D's primary liability. ${ }^{34}$ Similarly, she may be able to assert D's unrelated claims against C by way of set-off. ${ }^{35}$

Beyond such derivative claims, $\mathrm{G}$ is also entitled to raise certain rights and defenses against $C$ that $D$ could not raise- the socalled "suretyship defenses." For instance, if C modifies D's underlying obligation, extends D's time for performance, unreasonably refuses a tender of performance by either $D$ or $G$, or fails to supervise or preserve rights against collateral or against cosureties or sub-sureties, G may avoid liability to the extent she

\footnotetext{
${ }^{30}$ Restatement 3d $\S 22$ (cited in note 5). See also UCC § 3-419(e); UCC § 5-114.

${ }^{31}$ Restatement 3d $\S 29$ (cited in note 5). A party that is equitably subrogated to another acquires the legal rights and remedies of the latter.

${ }^{32}$ Id $\S 21 \&$ comment $i$.

${ }^{33}$ Id $\S 21$ comment $k$. See also UCC $\$ 2-609$ ("Right to Adequate Assurance of Performance").

${ }^{34}$ Restatement $3 d \S 34$ (cited in note 5).

${ }^{35}$ Id $\S 36$.
} 
suffers resulting loss. ${ }^{36}$ Indeed, if $\mathrm{C}$ fails to disclose events that would support a good suretyship defense under conditions where it should know that $G$ is ignorant of such events, $G$ has a right to recover any amounts she has unnecessarily paid out. ${ }^{37}$

The specific content of these various rights and duties, however, depends both upon the particular factual setting and the governing body of law. The substance of suretyship defenses and the duties of care owed by the creditor, for instance, are different under the common law of suretyship, Articles 3 and 9 of the UCC, and the law of letters of credit. ${ }^{38}$ The remedies that follow from a breach of C's duty to $\mathrm{G}$ are also different, ${ }^{39}$ as are the procedures for contracting around the default rules within various legal regimes. ${ }^{40}$ As a result, the content of guaranty obligations depends primarily on the parties' choice of transactional form. A person guaranteeing a promise embodied in a promissory note can opt into the rules of Article 3 by signing the note as an accommodation party ${ }^{41}$ or into the rules of the common law of suretyship by signing a separate written agreement. She can opt into Article 5 by casting her guaranty in the form of a letter of credit or opt into Article 9 by offering specific property as collateral. Even within these broader transactional forms, furthermore, she can vary her rights and duties by using particular terms of art, relying on the Article 3 distinction between guaranty of collection and guaranty

${ }^{36} \mathrm{Id} \S \S 37-46$.

${ }^{37}$ Id $\S 47$.

${ }^{38}$ For instance, while the creditor's release of the debtor presumptively releases the guarantor under the traditional common law of suretyship, it does not operate as a release under Article 3. Compare id § 39, with UCC § 3-605(b). Similarly, under the common law, the guarantor can raise most defenses against liability that are available to the debtor, including failure of consideration, breach of warranty, and the like. Under Article 3 , however, such defenses would not be good against a holder in due course, and under new Article 5 , they would be good only to the extent that they amounted to material fraud under UCC § 5-109. On these differences, see Cohen, 34 Wm \& Mary L Rev at 1037-40 (cited in note 1) (discussing defenses under Article 3); Peter A. Alces, An Essay on Independence, Interdependence, and the Suretyship Principle, 1993 U II L Rev 447, 465-76 (discussing and comparing defenses under Article 5 and the common law).

${ }^{39}$ Compare, for example, Restatement 3d $\S \S 37,42$ (cited in note 5), with UCC § 3605(e), (f).

${ }^{4}$ Compare Restatement 3d $\S 6$ (cited in note 5), and UCC $\S 3-605$ (i) (allowing guarantor to waive defenses based on suretyship and impairment of collateral), with UCC \& 9501(3) (limiting ability of guarantor and creditor to vary their rights and duties with respect to disposition of collateral prior to default; also barring the parties from varying other rights and duties).

${ }^{41}$ Of course, the note must also be negotiable for Article 3 to apply. Ronald J. Mann, Searching for Negotiability in Payment and Credit Systems, 44 UCLA L Rev 951, 962-85 (1997), presents empirical evidence that such negotiable promissory notes are relatively rare in modern business transactions. 
of payment, ${ }^{42}$ or by providing specific conditions for transfer and presentment in a letter of credit. ${ }^{43}$ By issuing a limited rather than an unlimited guaranty, she can mimic various risk-sharing devices common in insurance markets, including liability caps, deductibles, and copayments. ${ }^{44}$ And apart from a few exceptions, she can contract around the default rules of suretyship whatever the applicable legal regime. ${ }^{45}$ Indeed, such waivers of default are the norm in many lending markets. ${ }^{46}$

To decide whether to cast one's financial transactions in the form of a guaranty at all, to choose which regime of guaranty law to opt into, and to decide whether to accept the various default rules of that regime, accordingly, it is necessary to understand the economic purposes that guaranty contracts serve. In the next Section, I present an account of why guaranties exist-why and when it is desirable to divide the functions of providing funds and of bearing the residual risks of debtor default between two different parties, and why and when it is desirable to use a threecorner conditional arrangement when doing so.

\section{GUARANTIES AND THEIR ALTERNATIVES: THE CHOICE OF TRANSACTIONAL FORM}

In this Section, I discuss why parties would or should want to use guaranties, in contrast to the alternatives of unguaranteed lending and direct intermediation. The discussion proceeds as follows: first, I develop a simple model outlining the costs of credit, which include the lender's time value of money, monitoring efforts, the cost of liquid funds, and the probability that the debtor will default. Using this model, I show that guaranteed lending is more efficient than unguaranteed lending when G's monitoring and collection costs are sufficiently lower than C's, and C's liquidity costs are sufficiently lower than G's. I then go on

42 UCC \& 3-419(d).

${ }^{4}$ Id § 5-112 (providing that the beneficiary warrants that all necessary conditions of the credit have been complied with when she transfers a letter of credit or demands payment thereunder).

"See Alces, 1993 U IIl L Rev at 457-58 (cited in note 38). The nature of these limits depends on the type of guaranty used. For instance, if the guaranty takes the form of a put option on the underlying debt, the exercise price of the option implicitly determines the deductible. A face-value exercise price is equivalent to no deductible; lower exercise prices imply higher deductibles.

${ }^{4}$ See, for example, Restatement 3d § 6 (cited in note 5); UCC § 1-102. But see UCC § 9-501(3) for some possible exceptions.

${ }^{46}$ See Cohen, $34 \mathrm{Wm} \&$ Mary L Rev at 1042-43 (cited in note 1); Restatement 3d § 48 comment a (cited in note 5); Lynn M. LoPucki, et al, Commercial Transactions: A Systems Approach 514-19 (Aspen 1998). 
to show that guaranties are more efficient than intermediation when $\mathbf{C}$ places a sufficiently higher value on having a direct claim against $D$ than do G's other creditors and stakeholders.

The discussion focuses on the criterion of economic efficiency-that is, of maximizing the net surplus, monetary or otherwise, that results from the transaction. In most business dealings, the parties are motivated in substantial part by the prospect of economic gain and have the opportunity to plan their arrangements carefully and with the assistance of professional advisers. Because the law also allows them substantial leeway in shaping their contractual relationships, they have both the incentive and the ability to conserve on transaction costs. Thus, an efficiency analysis operates in this setting as both an explanatory theory of commercial actors' behavior and as a normative benchmark by which to judge their efforts. ${ }^{47}$

Before we begin the main discussion, however, two prefatory remarks regarding its scope are in order. First, although I often assume that the guarantor receives a direct benefit from the guaranty transaction, the analysis to follow applies equally well to guaranties that are formally uncompensated. Many, if not most, uncompensated guarantors have an economic interest in the success of the enterprise being guaranteed; even those with purely donative intent ordinarily will wish to offer their support in an efficient manner..$^{48}$

\footnotetext{
47 The usual caveats to such an approach, of course, will apply. See, for example, A. Mitchell Polinsky, Economic Analysis as a Potentially Defective Product: A Buyer's Guide to Posner's Economic Analysis of Law, 87 Harv L Rev 1655 (1974) (discussing and criticizing the technical assumptions of efficiency analysis); Arthur M. Okun, Equality and Efficiency: The Big Tradeoff (Brookings 1975) (discussing the tension between efficiency and distributional equity); Ronald M. Dworkin, Is Wealth A Value?, 9 J Legal Stud 191 (1980) (critiquing efficiency from a perspective of liberal individualism); Richard A. Posner, The Economics Of Justice 48-115 (Harvard 1983) (defending efficiency as normatively preferable to utilitarianism); Jules L. Coleman, Markets, Morals, and the Law 95-132 (Cambridge 1988) (critiquing efficiency criterion from the perspective of classical utilitarianism); and the various critiques surveyed in Avery Wiener Katz, ed, Foundations of the Economic Approach to Law 311-69 (Oxford 1998).

${ }^{48}$ Compare, for example, Steven Shavell, An Economic Analysis of Altruism and Deferred Gifts, $20 \mathrm{~J}$ Legal Stud 401, 409-19 (1991) (defining an efficient gift as one that minimizes unnecessary transaction costs while maximizing the value that the beneficiary actually receives from an outlay of given cost), with Richard A. Posner, Gratuitous Promises in Economics and Law, $6 \mathrm{~J}$ Legal Stud 411, 414-24 (1977) (explaining many formally donative promises in terms of self-interest). More specifically, there are numerous ways to assist a person in need of credit if that is one's purpose. One can lend the intended beneficiary funds at a below-market interest rate, guarantee his loan with another creditor, or directly subsidize his interest expeditures (perhaps an amount equal to the differential charged between high risk and low risk loans). Depending on the particular circumstances of the beneficiary and the donor, these various arrangements will have different costs and benefits, so that a guaranty may or may not be the most cost effective form of assistance.
} 
Second, and more importantly, my focus on efficiency is not intended to suggest that individual profit maximization always leads to a socially efficient outcome, or that actual guaranties are always motivated by efficiency considerations. On the contrary, the standard litany of market failures-scale economies, monopoly, externalities, and imperfect information-are just as relevant here as in any other exchange setting. For instance, if guarantors mistakenly underestimate the relative costs of making a guaranty, as some gratuitous guarantors surely do, private contracting will lead to too many guaranties and, conversely, to too few interest subsidies or direct low-interest loans. ${ }^{49}$ Similarly, the parties to a credit transaction may in many instances find otherwise inefficient arrangements to be privately profitable just because those arrangements allow the principals to impose externalities on nonparties. I will discuss such externalities, as well as analogous nonefficiency rationales for guaranties such as tax, accounting, and regulatory considerations, in Section II.B below.

\section{A. Guaranties, Unguaranteed Lending, and Intermediation}

Consider a situation where a would-be debtor, $D$, seeks funds from two potential creditors, C and G. There are several ways to provide funds to $\mathrm{D}$, the three main types of which are depicted in Figure 1, where arrows indicate the flow of credit. First, D could borrow from $\mathrm{C}$ alone, leaving $\mathrm{G}$ out of the transaction entirely; this possibility is depicted in part (a) of the figure. Second, D could borrow from $\mathrm{C}$ and supplement it with a guaranty from $\mathrm{G}$. This possibility is depicted in part (b) of the figure, with the dotted arrows indicating that the extension of credit is contingent rather than unconditional. Specifically, if $D$ does not repay the

As I will show below, the factors that determine whether a guaranty is efficient in the context of a gift are analogous to those that determine its efficiency in the context of a bargain.

49 Indeed, several important doctrines of suretyship law are motivated primarily by concern for the incautious or noncalculating guarantor. These include the special Statute of Frauds for suretyships, see Restatement $3 d$ \$ 11 \& comment a (cited in note 5), and the greater procedural and substantive scope given to suretyship defenses in the donative context, see, for example, id $\S 49$ \& comment b (providing that compensated, but not gratuitous, guarantors bear the burden of proof with regard to the extent of economic loss resulting from the creditor's improper actions). Modern consumer protection law offers additional safeguards for casual guarantors. See, for example, the FTC's Credit Practices Rules, especially those codified in 16 CFR \$ 444.3(a) (1998) (Unfair or Deceptive Cosigner Practices"). In addition, many courts have shown special solicitude to the unique formcontract and boilerplate problems arising from guaranty contracts, and have interpreted claims against guarantors strictly and suretyship defenses broadly. See generally Peter A. Alces, The Efficacy of Guaranty Contracts in Sophisticated Commercial Transactions, 61 NC L Rev 655, 660-61 (1983). 
primary loan, then $G$ will become indebted to $C$ and $D$ will become indebted to $G$. Third, $G$ could borrow from $C$ and then onlend to $\mathrm{D}$, a possibility depicted in part (c) of the figure. In this case both obligations are unconditional. $C$ would then have no direct claim against $D$, though G's claim against $D$ would be one of the assets to which $\mathrm{C}$ could ultimately look for satisfaction if $\mathrm{G}$ falls into default with C. $^{50}$

For each of these three possibilities there exists an alternative and symmetric arrangement with $\mathrm{G}$ and $\mathrm{C}$ switching places. For instance, D could borrow the entire amount from $G$ rather than from $\mathrm{C}$, and so on. Additionally, the parties could provide part of the desired funds through one form and the rest through another, as when C and G separately and independently lend D half of what he requests. These further alternatives are omitted from Figure 1 for the sake of simplicity, but they are discussed below where relevant.

\section{Figure 1. Alternative Configurations of Credit}

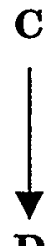

D

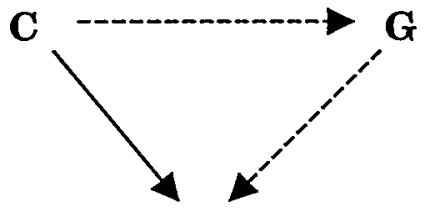

D
C

$\checkmark$

$\downarrow$

D
(a) Direct Lending
(b) Guaranty
(c) Intermediation

1. The cost of credit in an unguaranteed loan.

The precise costs of credit will vary depending on the form of the transaction. In the simple case where C lends directly to D, there are three main components of credit cost. The first is the marginal cost that $\mathrm{C}$ bears in obtaining liquid funds to lend, a cost that can be further divided into two subcomponents. The first of these subcomponents is the pure time value of money-the ex-

\footnotetext{
${ }^{50}$ The Bankruptcy Code provides that, as of the commencement of bankruptcy, all of a debtor's legal or equitable property interests, including unpaid accounts receivable, become property of the bankruptcy estate, to be collected and managed by the trustee for the benefit of creditors. 11 USC $\S 541$ (1994). In addition, the trustee has the discretion under id $\S 365$ to assume any executory contract rights of the debtor.
} 
plicit or implicit interest rate, $i_{c}$, that $\mathrm{C}$ must pay for obtaining such funds, whether by drawing down its own savings, reducing loans to other borrowers, or engaging in financial intermediation with other potential lenders. The second subcomponent is C's marginal cost of liquidity, $l_{c}$. Liquidity should be understood here in a Coasean sense-I use the term to denote the transaction costs that $\mathrm{C}$ must incur to convert its assets into a readily acceptable medium of exchange. ${ }^{51}$ If, for example, all of C's assets happen to be tied up in a parcel of real estate, its liquidity costs would consist of all the expenditures and opportunity costs associated with mortgaging or selling the parcel, including commissions, appraisals, surveys, title insurance, transfer taxes, attorneys' fees, and the like. The extent of such costs will of course depend on the particular form in which C's assets are held. If C's assets take the form of certificates of deposit, its liquidity costs may be limited to the interest penalties it incurs for early withdrawal; if C's entire wealth is held in the form of cash in a mattress, its immediate liquidity cost will be close to zero. In both cases, however, it is still necessary to consider the additional transaction costs that $\mathrm{C}$ will have to incur if it loans out all its cash and has to borrow more funds in an emergency, discounted by the probability of that event. ${ }^{52}$

The second main component of C's credit cost is the transaction cost of dealing with $\mathrm{D}$. These transaction costs include the ordinary incidents of processing a loan: underwriting; time spent by loan officers, clerks, and other administrators; drafting and executing a loan contract; and servicing the loan after it is made. They also include the costs of investigating D's creditworthiness and auditing his behavior over the life of the loan. Such monitoring costs will depend on the amount being lent, but, more importantly, will also turn on the precise nature of C's relationship with $\mathrm{D}$. If $\mathrm{C}$ has never dealt with $\mathrm{D}$ before, it will need to spend time acquainting itself with D's business affairs and credit history, the merits of any projects $D$ plans to pursue with the borrowed funds, other competing demands on D's resources, and similar matters, before making any loan. These costs will be lower if $\mathrm{C}$ has dealt with other persons in D's position in the past, and lower still if $\mathrm{C}$ has dealt with $\mathrm{D}$ personally. Conversely, if $\mathrm{C}$

${ }^{51}$ See James Tobin, Liquidity Preference as Behavior Towards Risk, 25 Rev Econ Stud 65,85 (1958) (discussing the relationship between risk aversion and investors' willingness to hold cash).

${ }_{52}$ Both of these determinants of C's cost of funds, interest and liquidity, in general will depend on the amount of credit being extended, but to simplify the discussion I will speak as if they are strictly proportional to the amount being lent. 
plans to deal with $D$ again in the future, these costs can be amortized over multiple occasions, while if this is an isolated transaction, such costs will have to be recovered all at once. ${ }^{53}$ Similar considerations apply to the costs of supervising the loan after it has been made, keeping track of D's other assets as well as any subsequent borrowing he may undertake, and maintaining the value of any necessary collateral. I will denote the marginal cost of such monitoring by the symbol $m_{c D}$, where the subscript CD emphasizes the relational aspects of these monitoring costs.

Third, even with optimal monitoring, some risk of debtor insolvency and default will still remain. The resultant loss to be expected depends on the probability of such a default, the amount of funds that can be recovered afterwards, and the cost of collection. All three of these quantities will depend on the amount of investigation and auditing that $\mathrm{C}$ has done, C's and D's individual characteristics, and external factors out of both parties' control. Furthermore, because $\mathrm{C}$ must accept this risk of insolvency and default if it is to lend at all, C's subjective assessments of risk, based on past experience with $\mathrm{D}$ and other debtors who appear in C's eyes to be similar, is also relevant. Again, to highlight the relational aspect of such considerations, I denote the marginal cost of this risk, as perceived by $\mathrm{C}$, as $r_{c D}$.

The total cost of credit under an unconditional loan from $\mathrm{C}$ to $\mathrm{D}$ is thus $i_{c}+l_{c}+m_{C D}+r_{C D}$. In a competitive credit market-that is, one in which $\mathrm{C}$ contends with many other potential creditors for D's business-this total cost will also determine the interest rate that $\mathrm{D}$ will have to pay for credit. A competitive market, of course, does not ensure that the cost of credit is low. If $D$ has little experience with borrowing, or if he resembles other debtors whose risks of default have been high in the past, or if the market's subjective opinion of him is simply unfavorable, then the competitive price of credit he faces will be high, because the expected monitoring and default costs of creditors dealing with him will also be high. Furthermore, if he faces a noncompetitive credit market, he will probably have to pay an additional mark-up above and beyond marginal cost. Still, there is no particular reason to think that the amount of any noncompetitive mark-up will depend on the nonprice terms of the loan, or that lender market power will result in an inefficient mix of auditing, investigation, or other terms. ${ }^{54}$

\footnotetext{
${ }^{53}$ See Scott, 86 Colum L Rev at 948 (cited in note 6) (emphasizing the importance of fixed investigative and monitoring costs in the credit context, and arguing that such costs explain why many individual debtor-creditor relationships tend to be long-term).

${ }^{s}$ In general, while noncompetitive markets tend to produce inefficiently high prices
} 
Conversely, if $\mathrm{D}$ borrows directly and unconditionally from $\mathrm{G}$, his expected price of credit will equal the quantity $i_{G}+l_{G}+m_{G D}+$ $r_{G D}$ - the sum of G's costs of interest, liquidity, monitoring, and anticipated default risk when dealing with $\mathrm{D}$ on such a basis. Whether $\mathrm{D}$ borrows from $\mathrm{C}$ or $\mathrm{G}$, however, he must also add his own personal transaction costs from borrowing to the market price of credit. These include not just time, trouble, and the expense of dealing with legal papers, but the costs of investigating and monitoring $\mathrm{C}$ and $\mathrm{G}$ in order to ensure that they themselves do not act in an opportunistic or negligent fashion. The size of these various transaction costs will depend on the nature of D's relationships with $\mathrm{C}$ and $\mathrm{G}$ and can be denoted as $t_{D C}$ and $t_{D G}$, respectively. Thus, when choosing between $\mathrm{C}$ and $\mathrm{G}$ as potential direct creditors, $\mathrm{D}$ should prefer to borrow where his total costs are least.

2. The cost of credit in a guaranty transaction.

The addition of a guarantor to the transaction unambiguously reduces C's costs, for several reasons. First, because C can anticipate that $G$ will rationally wish to engage in some monitoring of $\mathrm{D}$ and will also wish to help ensure that $\mathrm{D}$ performs, $\mathrm{C}$ can reduce its own monitoring efforts to a corresponding extent. Second, even if $G$ engages in no monitoring, her willingness to underwrite D's debt credibly signals her subjective belief that $D$ is relatively likely to perform. To the extent that $\mathrm{C}$ has reason to think G's risk assessments are accurate, this signal lowers its own expected costs of monitoring and default. (Consider a mother with two sons, one industrious and one irresponsible. Because the mother knows that the former son is less likely to default than the latter, the expected cost to her of giving him a guaranty is lower. Other things being equal, accordingly, she is more likely to guarantee the former's debt than the latter's. ${ }^{55}$ )

(that is, prices in excess of marginal costs), they have no particular tendency toward inefficient nonprice terms. On the contrary, a profit-seeking monopolist or oligopolist will ordinarily want to choose the nonprice terms that best suit the preferences of the marginal consumer, for this maximizes the mark-up he or she can charge. For fuller explanations of this point, see A. Michael Spence, Monopoly, Quality, and Regulation, 6 Bell J Econ 417, 428 (1975); William S. Comanor, Vertical Price-fixing, Vertical Market Restrictions, and the New Antitrust Policy, 98 Harv L Rev 983, 990-98 (1985); Richard Craswell, Passing On the Costs of Legal Rules: Efficiency and Distribution in Buyer-Seller Relationships, 43 Stan L $\operatorname{Rev} 361,373-76$ (1991).

ss Unless she feels that the industrious son, being better able to take care of himself, is in less need of her largesse. But even so, the spendthrift's default risk to creditors makes a guaranty a relatively costly way of helping him, so the use of the guaranty form still has informational value to a creditor. 
Third, to the extent that $D$ values his relationship with $G$, cares about G's welfare, or anticipates that $G$ will be better able to collect than will $\mathrm{C}$ alone, $\mathrm{D}$ has incentives to take greater precautions against default. And, fourth and most obviously, should $\mathrm{D}$ become insolvent, $\mathrm{C}$ will have a backup source of funds to pursue. Except in the extreme case where D's and G's assets are essentially the same (as with a parent and subsidiary corporation that operate de facto as a single entity), the chance that both $D$ and $\mathrm{G}$ will become insolvent simultaneously is an order of magnitude less than the chance that either one will become insolvent alone. ${ }^{56}$

As a result, $\mathrm{C}$ would plainly prefer adding $\mathrm{G}$ to the transaction if there were no costs associated with doing so. But of course there is a cost-the risks and obligations that will be imposed on $G$ in her role as guarantor. To the extent that $C$ is relieved from the responsibility for monitoring, $G$ is burdened with it. To the extent that $\mathrm{C}$ can recover from $\mathrm{G}$ following D's default, $\mathrm{G}$ (and G's other creditors) are at risk. Thus, many, though not all, of the costs saved by $\mathrm{C}$ on a guaranteed loan are simply shifted to G.

We can analyze these costs of guaranties more formally. First, we start with C's costs of interest, liquidity, monitoring, and default risk: $i_{c}+l_{c}+m_{C D 1 G}+r_{C D \mid G}$. (The notation $C D \mid G$ denotes C's cost of dealing with $D$ given that $G$ is also in the transaction; note that these costs now include C's efforts to monitor G.) C's interest and liquidity costs are unchanged by G's presence in the transaction, but its combined monitoring and default risk costs are lower for the four reasons explained above: $m_{C D I G}+r_{C D 1 G}<m_{C D}$ $+r_{c D}$.

Next, we must consider the expected costs that $G$ incurs in her role as guarantor. First, while G need not pay interest costs in order to provide a guaranty, she does incur some monitoring costs. Second, she will also perceive some risk that D will default; this perception depends on her own assessment of D's situation, the investigative efforts she undertakes, and her ability to collect. Both of these costs, furthermore, are influenced by C's involvement in the transaction. The influence can cut one of two ways. In the event that C's monitoring and investigation decreases D's chances of default, G's costs of monitoring and collection will be lowered; on the other hand, if $\mathrm{C}$ behaves opportunistically toward

\footnotetext{
${ }^{56}$ This last factor explains why the wealth, financial strength, and credit reputation of the guarantor matter to lenders in actual guaranty transactions. Additionally, to the extent that $G$ turns out to be judgement-proof after the fact, her incentives to monitor the debtor or accurately to signal his default risk are attenuated. On the importance of guarantor financial strength, see Section II.A.4.b.
} 
D or toward the collateral, G's costs may increase. (Indeed, for this reason $G$ may wish to engage in some investigation and monitoring of $\mathrm{C}$ as well as of D.) Accordingly, G's monitoring and default costs under a guaranty will depend on her relationship with $\mathrm{C}$, and are denoted here as $m_{G D 1 C}$ and $r_{G D I C}$, respectively.

Third and finally, in the event of a default G not only must pay out on her guaranty, she must also raise the necessary funds to do so; this will force her to incur liquidity costs at that time. Since such liquidity costs need not be paid up front, however, they can be discounted by the probability of a default, $r_{G D I C}$. Thus, G's total expected costs from a guaranty will equal $m_{G D I C}+r_{G D I C}$ (1 $\left.+l_{G}\right)^{.57}$

Let us now consider D's perspective on this transaction. In a competitive credit market, $D$ will have to pay the sum total of C's costs and G's costs in order to obtain a guaranteed loan. ${ }^{58}$ On top of that $\mathrm{D}$ must consider his own transaction costs of dealing with $\mathrm{C}$ and $\mathrm{G}$, both of which will depend on his prior relationship with those parties. The total costs of dealing with both $\mathrm{C}$ and $\mathrm{G}$ together, moreover, are likely to be higher than the cost of dealing with either one individually under a direct unconditional loan. I denote these transaction costs as $t_{D C \mid G}+t_{D G I C}$.

Without resorting to a great deal of tedious algebra, it should be apparent that a loan made by $\mathrm{C}$ and guaranteed by $\mathrm{G}$ is cheaper than a simple unguaranteed loan from $\mathrm{C}$ if, and only if, the expected savings achieved by shifting some or all monitoring, enforcement, and default risk costs from $\mathrm{C}$ to $\mathrm{G}$ outweigh the increased transaction costs that arise from having to maintain three relationships among the parties instead of just one. ${ }^{59}$ In short, guaranties are profitable when the guarantor holds a sufficiently great comparative advantage in investigating, supervising, or collecting from the debtor in the event of default-in other words, when the guarantor is the least-cost monitor. The creditor and debtor engage the guarantor to do this monitoring and enforcement, either explicitly or implicitly, and the guarantor either

\footnotetext{
${ }^{57}$ For simplicity, I am assuming here that default, if it occurs, takes place at the end of the loan period. Thus G gets to keep her funds throughout the life of the loan, and accordingly incurs no interest costs.

${ }^{58}$ This is so even if the guaranty is a gratuitous one, because G's ability and inclination to make gifts to $\mathrm{D}$ is presumably finite; any costs she incurs in making the guaranty will reduce the funds she has available for alternative or future gifts. Thus, $D$ must count the direct costs to $G$ as an approximation of the opportunity costs to him resulting from such a reduction.

${ }^{59}$ For aficionados of tedious algebra, the formal derivation is left as an exercise for the reader.
} 
keeps the proceeds as her compensation or allows the debtor to keep them as a gift. ${ }^{60}$

This explanation of guaranties fits well with the stereotypical examples presented in Section I. Consider first the case of intrafamilial guaranties. Parents generally know their children better than third-party lenders do. They are ordinarily familiar with their children's past financial behavior and in most cases have relatively more accurate information about their children's day-to-day doings. The emotional aspects of ordinary family life also help to reduce parents' costs of monitoring and collection. Because of the awkwardness and guilt most adults feel when in debt to their parents, and because of the utility they attach to their parents' welfare, children will work harder to avoid defaulting when parents are potentially liable for filial debts. In the event of default, furthermore, the parents are also better placed than an outside creditor would be to collect from their children, not only because they have better information about hidden assets, but because the perceived moral obligation to repay a family member for a bad loan is likely to survive bankruptcy where a commercial obligation does not, and because ultimately parents have the option of collecting by reducing future gifts and bequests. ${ }^{61}$

Similarly, controlling shareholders hold a comparative advantage in investigating, supervising, and collecting from the corporations they oversee. As residual claimants, they enjoy the marginal benefits and suffer the marginal costs of corporate actions, hold the balance of power for certain critical decisions, and may even be entitled to dissolve the company entirely. All these considerations make them good candidates to guarantee corporate debts. Parent companies have similar comparative advantages in monitoring and collecting from their subsidiaries, and sibling companies from their siblings. Subsidiary companies may even have a comparative advantage in monitoring their corporate parents, especially when there is common or overlapping management.

\footnotetext{
${ }^{6}$ In this regard, the issue can be reframed as one of the optimal level of vertical integration in the provision of credit services. For simple loans, the lender does all the risk assessment, monitoring, and enforcement in-house, but sometimes it is cheaper to subcontract some or all of these tasks to a specialist. Similarly, it might be cheaper to specialize even further, and hire someone to monitor and insure against just one particular kind of risk; the case of title insurance comes to mind here. Thanks to Victor Goldberg for suggesting this example.

${ }^{61}$ On all these considerations, and for a general discussion of implicit financial contracts between parents and children, see Gary S. Becker and Kevin M. Murphy, The Family and the State, $31 \mathrm{~J}$ L \& Econ 1, 1-8 (1988).
} 
The general practice of standby letters of credit can also be understood in such terms. Commercial banks will have a comparative advantage in monitoring their existing credit customers, as their prior relationships with such customers allow them to obtain and evaluate relevant information at low cost. They also have many more ways to influence such debtors' behavior after a loan is made. For instance, they can call in, refuse to renew, or exercise covenants on separate loans. In addition, they may have established general "floating liens" on the debtor's property-that is, mortgages or security interests that cover after-acquired property or that provide that existing collateral will also serve to secure future advances. ${ }^{62}$ Such cross-collateralization clauses improve the bank's ability to collect on any advances it makes pursuant to a guaranty; they also give the bank substantial leverage over the debtor by making it difficult for him to engage in subsequent borrowing without the bank's permission. ${ }^{63}$ Perhaps most importantly, the prior relationship gives the bank the power to ruin the customer's reputation with other lenders. Because an unfavorable credit reference from a longstanding creditor carries great weight in underwriting decisions, the bank can credibly threaten to raise the customer's cost of borrowing for the foreseeable future. Such a threat serves as a powerful incentive for D to repay ${ }^{64}$ For all these reasons, then, bank guaranties-cast in the form of standby letters of credit-can substantially cut the expected costs of monitoring, default, and collection relative to unguaranteed loans.

Construction suretyships and payment bonds have a similar underlying motive. ${ }^{65} \mathrm{~A}$ general contractor overseeing a construction project typically obtains significant advances from the proj-

${ }^{62}$ Under UCC \$ 9-204, for instance, parties to a security agreement may provide that any assets that $\mathrm{D}$ acquires before or after the agreement will serve as collateral for any advances that the bank makes, including any payments that the bank makes pursuant to a guaranty. With limited exceptions-id §§ 9-301(4), 9-307(3), and 9-312(3),(4),(7)-a security interest based on future advances will have the same priority over competing creditors as the original security interest created by the agreement.

${ }^{\infty}$ See Ronald J. Mann, The Role of Secured Credit in Small-Business Lending, 86 Georgetown L J 1, 25-26 (1997) (arguing and presenting empirical evidence that the primary motivation for secured credit is to limit subsequent borrowing by the debtor).

${ }^{*}$ On the value of ruining a reputation as a contractual enforcement device, see, for example, David Charny, Nonlegal Sanctions in Commercial Relationships, 104 Harv L Rev 373, 408-26 (1990); Lisa Bernstein, Opting Out of the Legal System: Extralegal Contractual Relations in the Diamond Industry, $21 \mathrm{~J}$ Legal Stud 115, 138-43 (1992).

${ }^{65}$ Thanks to Jim Bowers for suggesting this example and a good part of its analysis. Similar considerations apply in other businesses besides construction. See, for example, Mark C. Phillips, The Role of Completion Bonding Companies in Independent Productions, 12 Loyola LA Enter L J 97, 107-18 (1992) (describing the role of guarantors in the motion picture industry). 
ect's overall sponsor and small-scale trade credit from a variety of project participants: subcontractors, mechanics, and materialmen. Rather than having each of these participants undertake the costs of investigating the contractor's credit and monitoring his use of funds, however, it is far cheaper to hire a professional surety company to do the job and bear the associated risk of default. This arrangement saves on duplicative monitoring efforts and better allows the various trade creditors to focus on their respective comparative advantages in plumbing, paving, and the like, enabling them to submit lower bids. The surety, due to its experience in the industry, is also likely to be more effective than the sponsor at picking up the pieces of the project and seeing it to conclusion should the contractor withdraw. Accordingly, using a surety should lower the expected cost of project completion by more than enough to cover the required payment bond.

Finally, the example of joint and several liability among apartment cotenants also fits our generic explanation. Apartment roommates have an independent and ongoing incentive to investigate and supervise each others' reliability. They regularly extend each other petty credit in connection with shared household expenses and, more importantly, share access to each others' personal property. They are also privy to each others' daily comings and goings. With regard to claims such as damage to common areas, furthermore, the landlord is typically unable to determine individual responsibility at reasonable cost. It makes sense, therefore, for landlords to hire roommates to monitor each other by providing for joint and several liability rather than contracting for several liability alone-at least up to the liquidated amount of a security deposit.

One clarification to the analysis is perhaps in order. In many cases, the guarantor has a comparative advantage in monitoring or collection because she is in significant part promising to monitor or collect from herself. Much default risk, after all, results from debtors' opportunistic collusion with other parties. In the corporate and familial settings especially, guaranties are commonly used to guard against just such misbehavior. For instance, because of limited liability, creditors of corporate debtors need to worry not only about whether the underlying project being financed is sound; they also must worry whether the proceeds of the loan will remain within the corporation or be funneled to a controlling owner, related entity, or other insider. Minimum capital requirements, the corporate law duties of care and loyalty, fraudulent conveyance law, and the doctrine of piercing the cor- 
porate veil all substantially help to police such misbehavior. ${ }^{66}$ In addition, however, many lenders also insist on receiving guaranties from those actors deemed most subject to temptation; for example, controlling shareholders. Similarly, a lender contemplating a loan to an individual borrower will often insist on receiving a guaranty from the borrower's spouse, especially if the spouse holds a shared interest in property pledged as collateral or otherwise holds the power to disrupt attempts at collection.

3. Why does the guarantor guarantee rather than simply lend?

The foregoing account of guaranties is straightforward and intuitive, but it is not the complete story. If guarantors have a comparative advantage with investigation, supervision, and collection, why don't they just make loans themselves, thus saving the extra transaction costs of a three-corner relationship? Or, to choose a concrete example, why do commercial banks issue standby letters of credit to their longstanding customers instead of just extending additional advances under an existing line of credit? The answer cannot be that they wish to limit their exposure, because the terms of the standby credit make them liable for its face value in the event of default. Banks' desire to exploit loopholes in federal lending regulations may have partly explained their use of standby credits in the early 1980s, but today those loopholes have largely (though not entirely) been closed. ${ }^{67}$ Is there, then, an efficiency explanation?

There is, and it is evident when we recognize that monitoring, investigation, and collection are only part of the cost of credit. Recall that G's credit costs as a direct lender also include her implicit interest rate $i_{G}$ and her liquidity $\operatorname{cost} l_{G}$. As a guarantor, however, $\mathrm{G}$ avoids paying for implicit interest during the period the loan is outstanding, and she only need pay for liquidity in the event of a default. Interest and liquidity costs do not disappear if $\mathrm{G}$ acts as guarantor, of course; they are simply transferred to the primary creditor C. But if C's cost of liquid funds is

\footnotetext{
${ }^{66}$ Guaranties by subsidiaries of their parent companies pose some special legal problems because the owners of the parent have diluted incentives to ensure that the subsidiary receives fair value for guaranteeing the parent's obligations. In the event that the subsidiary becomes insolvent, its creditors are likely to attack the guaranty as a fraudulent conveyance or an impairment of required capital. On the problems raised by such "upstream" guaranties, see William H. Coquillette, Guaranty of and Security for the Debt of a Parent Corporation by a Subsidiary Corporation, 30 Case W Reserve L Rev 433, 438-60 (1980).

${ }^{67}$ See text accompanying notes $96-97$.
} 
sufficiently lower than G's, it can more than make up for the extra information and transaction costs incurred by a three-corner arrangement.

The point is easily demonstrated with a numerical example. Consider the situation of a debtor $D$ who applies for a $\$ 10,000$ loan from a potential creditor C, to be repaid after one year. Suppose for purposes of the example that the risk-free interest rate is 4 percent, reflecting the going rate of return on one-year Treasury bills, and that $\mathrm{C}$ has ready access to liquid assets at no additional cost beyond this risk-free rate. ${ }^{68}$ Suppose also that if $\mathrm{C}$ lends to $\mathrm{D}$, it will incur monitoring costs equal to 1 percent of the face value of the loan, and that even after such monitoring, there will remain a 15 percent chance of default. In this case, $\mathrm{C}$ will insist on charging a risk-adjusted interest rate of 20 percent $(=4$ percent + 1 percent +15 percent) if it makes the loan. Depending on the project $\mathrm{D}$ is planning to finance, such a high cost of funds may prevent the transaction from going forward; even if $\mathrm{D}$ is willing and able to pay C's required rate of return, it may exceed the price ceiling established by local usury laws. ${ }^{69}$

Alternatively, suppose that if $D$ borrows from $G$ instead of from $\mathrm{C}, \mathrm{G}$ 's superior ability to monitor and collect from $\mathrm{D}$ will cut the expected cost of default to 10 percent. Adding this default risk to the risk-free interest rate of 4 percent and monitoring costs of 1 percent makes G's cost of liquid credit 15 percent. ${ }^{70}$ But G holds her assets in a relatively illiquid form, and thus bears a further 10 percent cost in making them available for use by $D$. This raises G's required interest rate to 25 percent, making her a less desirable lender, both from D's private viewpoint and from the social viewpoint of economic efficiency.

If $\mathrm{C}$ makes the loan and $\mathrm{G}$ guarantees it, however, C's access to liquid funds will keep the direct cost of the loan down to 4 percent, and G's superior monitoring ability will keep the cost of de-

\footnotetext{
${ }^{68}$ For simplicity, we might imagine that $\mathrm{C}$ finances the loan to $\mathrm{D}$ by reducing its purchases of government bonds by $\$ 10,000$. More generally, as the preceding discussion makes plain, all market interest rates can be decomposed into components attributable to pure time value, liquidity, risk, and transaction costs. The precise assumption necessary here is that $\mathbf{C}$ has no additional cost of liquidity above and beyond whatever liquidity component is implicit in the risk-free market rate.

${ }^{69}$ See, for example, Ark Const, Art 19, $\S 13$ (maximum lawful interest rate is equal to 5 percent above the Federal Reserve discount rate at the time of the loan); Conn Gen Stat Ann $\S 37-4$ (West 1996) (maximum rate of 12 percent); Fla Stat Ann I $\$ 687.03$ (West 1990) (maximum rate of 18 percent on loans less than $\$ 500,000$ ).

${ }^{70}$ To keep the calculations simple, the example assumes that G's comparative advantage in monitoring is reflected only in a reduced probability of default. The argument would be analogous, though more complex, in the case where her out-of-pocket costs of monitoring are also lower than C's.
} 
fault down to 10 percent. Of course, $G$ will have to provide liquid funds in the event of a default, but that event can be discounted by its low probability. Thus while G's liquidity costs under a direct loan are 10 percent, her expected liquidity costs under a guaranty are equal to 10 percent of 10 percent, or 1 percent. Summing up, interest costs of 4 percent plus monitoring costs of 1 percent plus default costs of 10 percent plus liquidity costs of 1 percent equals 16 percent. Of course, there are additional costs of structuring the transaction as a guaranty, including the costs of duplicative monitoring by $\mathbf{C}$ and $\mathbf{G}$. If we denote these additional transaction costs as $t$, then the total cost of credit under a guaranty becomes 16 percent $+t$. If $t$ is low enough-specifically, if $t$ is less than 4 percent-then a guaranty will be cheaper and more efficient than a direct loan from either $\mathrm{C}$ or $\mathrm{G}$.

A guaranty, in short, is a credit transaction in which one party - the guarantor-specializes in information and monitoring, and another-the creditor-specializes in obtaining loanable funds. All of the guaranty arrangements described above accord with this basic principle. Let us examine a few of them as illustrations.

Consider first our example of the standby letter of credit. At any given moment, the marginal cost of interest and liquidity varies among large commercial banks. Such banks have different mixtures of long-term and short-term loans in their asset portfolios, and different risk exposures based on the specific commercial activities of their customers and on the particular investment products they have decided to back. Therefore, it can make sense for a bank with relatively heavy exposure in the area of commercial real estate, for instance, to decide that its marginal cost of liquidity is too high to justify a new loan to a longstanding client at market rates. If the client can obtain liquid funds elsewhere, however, the bank can trade on its informational investment in him by issuing a standby letter of credit in his favor. Conversely, another bank with temporarily superior access to a pool of liquid funds due, for instance, to a special relationship with an institutional depositor, may find it worthwhile to make a loan to an untried applicant if that applicant's current lender is willing to stand behind him. The standby letter of credit thus allows the debtor to benefit from the low monitoring cost that comes from establishing a long-term financing relationship while still retaining the option of shopping around for the best pure price on liquid funds. ${ }^{71}$

\footnotetext{
${ }^{71}$ In addition, the distinctive risk profile of a guaranteed loan may give it positive di-
} 
Similarly, consider how our basic explanation operates in the context of a recourse sale or assignment of accounts receivable. Under this arrangement, a retailer sells receivables to an account financer or factor, promising to repay the factor for any accounts that turn out to be uncollectible. ${ }^{72}$ In the framework of our model, the factor takes the role of the creditor, the retailer takes the role of guarantor, and the consumers take the role of debtor. Asking why the guarantor doesn't just lend in this context is equivalent to asking why the retailer doesn't just keep her accounts instead of factoring them. The answer, obvious to anyone familiar with the business of factoring, is that the retailer wants the money now instead of later. She wants liquid funds with which to pay current expenses and restock inventory, and this is her cheapest means of borrowing to obtain them. The factor, which has superior access to loanable funds, provides her with those assets in exchange for the discount it gets on the accounts. But because the retailer is familiar with her own customer base, and because the value of the accounts depends on the future repair or warranty services she provides to these customers, she thus appropriately bears the risk of consumer nonpayment. ${ }^{73}$

The typical circumstances surrounding the standard intrafamilial guaranty also comport with our theory. A parent may be highly confident in her child's ability to repay a loan and have quite effective means at her disposal to ensure that he actually does repay. As a result, she is willing to guarantee the loan while receiving relatively little in exchange; indeed, the expected cost to her may be low enough to justify making her guaranty a gift. But because the family assets are tied up in the house and in the parents' retirement savings accounts, making the same loan out of pocket would be quite expensive. If the child should default, of

versification value when combined with the rest of the issuer's lending portfolio. See, for example, M. Kabir Hassan, An Empirical Analysis of Bank Standby Letters of Credit Risk, 2 Rev Fin Econ 31, 38-42 (1992) (presenting evidence of such value for the largest U.S. banks and holding companies). But see Elijah Brewer, III and G.D. Koppenhaver, The Impact of Standby Letters of Credit on Bank Risk: A Note, $16 \mathrm{~J}$ Bank \& Fin 1037, 1040-44 (1992) (presenting empirical evidence that the overall risk of issuing standby letters of credit is similar to the risk of balance sheet lending).

"Or alternatively, the factor could make a secured loan to the retailer with the accounts serving as collateral. With minor exceptions, these two arrangements are legally and functionally equivalent. See UCC § 9-102(1)(b) \& comment 2.

${ }^{73}$ Conversely, if she were not the cheaper monitor, the sale would be on a nonrecourse basis, not a recourse one. The factor would then act as a direct lender, bearing the risk of default as well as providing liquid funds. See Janet Kiholm Smith and Christjahn Schnucker, An empirical examination of organizational structure: The economics of the factoring decision, $1 \mathrm{~J}$ Corp Fin 119, 126-35 (1994) (presenting evidence that factors are more likely to be used to finance trade credit on what is effectively a nonrecourse basis, other things being equal, when the seller's information and monitoring costs are high). 
course, the IRAs would have to be cashed in and the house mortgaged; but the chance of this happening is low-low enough to be outweighed by the benefits conferred on the child.

Our model is also broad enough to encompass at least one plausible nonpecuniary explanation for guaranties within the family. It has often been claimed that arms-length economic transactions between friends and family members weaken the bonds of friendship and clan loyalty. For instance, Steven Kelman has suggested that market interactions can lead to a "feelingfalloff" effect that leads people to devalue their personal relationships with those with whom they deal. ${ }^{74}$ Some feminist critics of law and economics, notably Frances Olsen and Margaret Jane Radin, have argued that economic analysis (and economic analysis of family law in particular) tends to commodify family relations, undermining the love and altruism that are essential to the maintenance of household cooperation and the healthy upbringing of children. ${ }^{75}$ If such claims are true, and if a direct debtorcreditor relationship is somehow more destructive of familial feeling than are the indirect and contingent obligations that arise from a guaranty, then guaranties will conserve on such psychic and emotional costs in the same way they conserve on liquidity costs. Given the possibility of default, there is always a chance that any guaranty will turn into an unconditional debt, with resulting cost to both fisc and fabric of the family unit. But these costs can be discounted substantially if the probability of incurring them is low.

4. Why doesn't the guarantor simply act as an intermediary?

We are not quite done with the analysis. The guarantor's comparative advantage in monitoring, risk assessment, and collection explains why she should bear the residual risk of the debtor's default; the creditor's comparative advantage in liquidity explains why it should obtain the funds. But neither explanation tells us why the relationship should take the form of a guaranty, for these same advantages could be achieved through pure intermediation or on-lending. Specifically, $\mathrm{C}$ could obtain funds and lend them to $\mathrm{G}$, who could then turn around and lend to $\mathrm{D} .{ }^{76} \mathrm{Un}$ -

\footnotetext{
${ }^{74}$ Steven Kelman, What Price Incentives: Economists and the Environment 57-69 (Auburn House 1981).

${ }^{75}$ Frances E. Olsen, The Family and the Market: A Study of Ideology and Legal Reform, 96 Harv L Rev 1497, 1560-78 (1983); Margaret Jane Radin, Market-Inalienability, 100 Harv L Rev 1849, 1921-36 (1987).

${ }^{76}$ Or, alternatively, we could reverse the timing: G could first lend to D and then re-
} 
der such an arrangement, $\mathrm{G}$ would bear the costs of monitoring $\mathrm{D}$ and dealing with any default on his part, since she would remain liable to $\mathrm{C}$ whether or not $\mathrm{D}$ managed to repay. $\mathrm{C}$ would bear the costs of liquidity, since it would be the one who obtains the funds. There would, moreover, be only two relationships to manage instead of three. What, then are the advantages of guaranties as opposed to intermediation? Or to put the question differently, what are the advantages of giving $\mathrm{C}$ a direct right of recovery against $\mathrm{D}$ as well as against $\mathrm{G}$ ?

It turns out that there are two answers to this question, which I take up in sequence. First, G's comparative advantage in supervising $D$ may be incomplete, so that it pays for $G$ to undertake some aspects of monitoring, risk assessment, or collection and for $\mathrm{C}$ to undertake others. Second, there is always a chance that $\mathrm{G}$ herself may default on her obligations to $\mathrm{C}$. If she does, giving $\mathrm{C}$ a direct right against $\mathrm{D}$ allows $\mathrm{C}$ to avoid sharing the proceeds of D's loan with G's other creditors, in much the same way that a security interest confers priority over rival creditors.

a) Specialization in different types of monitoring or enforcement. Recall that monitoring, as we have used the term, incorporates a wide variety of distinct business functions: underwriting, credit investigation, drafting and executing contracts, auditing, and the like. Similarly, collection may involve pursuing legal or nonlegal sanctions against the debtor, locating and gathering his assets, salvaging and reselling them, and, ultimately, bearing the risk that the proceeds will be inadequate to cover the debt.

It is quite possible for $\mathrm{G}$ to have a comparative advantage in some of these tasks and $\mathrm{C}$ to have a comparative advantage in others. If so, it is efficient to have $\mathrm{C}$ and $\mathrm{G}$ specialize in different types of monitoring or enforcement. Consider, for example, a loan made for the purposes of financing a startup enterprise. The borrower's family members may be better able to assess his overall honesty and industriousness, keep track of his personal assets, and collect from him in the event of a business failure. On the other hand, they may know relatively little about the specific line of business he is contemplating or may lack experience in evaluating whether such startup projects have what it takes to succeed. For these reasons, they may not wish to incur the risk of financing the project out of their own funds. Once a commercial lender with background in the relevant industry has evaluated and underwritten the project, however, the residual risk to the 
family members from guaranteeing the borrower's debt is substantially lowered.

One way to achieve such specialization, of course, is through direct subcontracting of the relevant activities-one party could make the loan and hire another party to conduct underwriting or collection. Indeed, such subcontracts are not uncommon, as the existence of the credit reporting industry illustrates. But the very fact that one party has a comparative advantage in some aspect of monitoring or enforcement may make it difficult for the other interested parties to tell whether he or she is carrying out such tasks effectively. For that reason, monitors and enforcers are typically allocated some portion of the risk of default; for instance, a collection agency hired to hunt down delinquent accounts might be paid a commission based on the amounts it actually manages to extract from recalcitrant debtors. Thus, to make use of C's and G's comparative advantages, it is necessary to provide both with incentives to perform their assigned tasks.

A guaranty promotes such dual incentives better than pure intermediation. Under intermediation, the risk of $D$ 's default is borne almost entirely by $\mathrm{G}$ and hardly at all by $\mathrm{C}$. $\mathrm{C}$ has no direct connection with $\mathrm{D}$ and no specific obligation to monitor him; indeed, so long as $G$ retains other assets sufficient to repay her loan, $\mathrm{C}$ is fully protected against loss. Under a guaranty contract, in contrast, both $\mathrm{G}$ and $\mathrm{C}$ have good incentives to engage in monitoring. G's incentives to monitor D are obvious-absent some excuse or defense, she will be liable for his default. C's incentives, however, arise from the fact that if it fails to act reasonably or to live up to its other contractual obligations, G will acquire just such an excuse or defense, for under the law of suretyship and guaranty, C owes special duties toward G-duties it does not owe to other ordinary creditors or debtors. These are the so-called "suretyship defenses." Failing to perform duties owed the debtor, failing to maintain rights against the debtor or against any collateral, granting the debtor unreasonable extensions or modifications-all operate in the guaranty context to release the guarantor from her obligation. As Section 37 of the Third Restatement provides: "If the obligee acts to increase the secondary obligor's risk of loss by increasing its potential cost of performance or decreasing its potential ability to cause the principal obligor to bear the cost of performance, the secondary obligor is discharged." 36-37.

${ }^{7}$ Restatement $3 \mathrm{~d} \S 37$ (cited in note 5). See also the discussion accompanying notes 
The law of suretyship, accordingly, provides both C and G with incentives to engage in monitoring, in the same way that negligence law provides dual incentives to take precautions against accidents and contract law provides dual incentives for parties to mitigate damages. Under each of these regimes, one party-the guarantor in surety, the victim in tort, the promisor in contract-is presumptively liable for a loss, and so has optimal incentives to take care to prevent it. The presumption is reversed, however, if the other party breaches a legal duty of care. The threat of that reversal gives that other party-the primary creditor $\mathrm{C}$, the potential tortfeasor, the contract promisee-strong incentives to take care. This result has been called "double responsibility on the margin."

Of course, it is not always efficient for law or contract to try to give both parties incentives to take care. If there is relatively little that one side can do to influence the underlying risk, or if the tribunal charged with enforcing the relevant duty of care is not good at determining whether it has really been breached, then the attempt to provide dual incentives may be more costly than it is worth. This is why, for instance, strict liability in tort is sometimes more efficient than a negligence rule. ${ }^{79}$ Similarly, if one of the parties already has good incentives to take care based on extralegal considerations such as reputation, it may be better for that party to disclaim liability for negligence or similar breaches of duty, reserving legal sanctions for the purpose of motivating the party not subject to such extralegal incentives. ${ }^{80}$ For all these reasons, then, it may be desirable in some cases to cast a

${ }^{78}$ Robert Cooter, Unity in Tort, Contract, and Property: The Model of Precaution, 73 Cal L Rev 1, 28 (1985).

${ }^{7}$ See Steven Shavell, Strict Liability Versus Negligence, 9 J Legal Stud 1, 10-22 (1980) (formal comparison of precaution incentives under competing rules); Guido Calabresi and Jon T. Hirschoff, Toward a Test for Strict Liability in Torts, 81 Yale L J $1055,1074-84$ (1972) (informal comparison of incentives). Similar considerations of relative ability to reduce risk and institutional capacity also determine which party should be presumptively responsible for a loss under a negligence-type rule and which party's breach of duty should operate to reverse that initial presumption. For instance, if courts are extremely good at detecting and punishing unreasonable behavior on the part of injurers, negligence is the most efficient rule of tort liability. Conversely, if courts are better able to evaluate victims' behavior, it is better to have a rule of strict liability with a defense of contributory negligence. Calabresi and Hirschoff, 81 Yale L J at 1074-84. In the guaranty context, analogous factors determine which party-C or G-should take the role of creditor and which party should take the role of guarantor.

${ }^{*}$ See, for example, Benjamin Klein, Transaction Cost Determinants of "Unfair" Contractual Arrangements, 70 Am Econ Assn Papers \& Proceedings 356, 358-60 (1980) (defending the unrestricted right of franchisors to terminate franchise contracts without proof of cause, on grounds that their tendencies toward opportunism are restrained by reputation while franchisees' are not). 
credit transaction in the form of an intermediation rather than as a guaranty. Such factors can also help explain why it might be efficient for guarantors to waive their rights to assert the standard suretyship defenses; indeed, such explicit waivers are routine in many important commercial settings. ${ }^{81}$

b) Risk of G's insolvency or recalcitrance. A second and equally important reason why guaranties may be preferable to intermediation is that $\mathrm{G}$ herself may fall into default and prove uncollectable. ${ }^{82}$ In this event, a guaranty contract gives $\mathrm{C}$ an alternate means of expedited collection, as well as partial priority over G's other creditors. Indeed, from a functional perspective, a guaranty is analogous to a secured loan by $\mathrm{C}$ to $\mathrm{G}$, with D's promise to pay operating as the collateral.

Specifically, in the event that G defaults or becomes insolvent, guaranties and intermediation have different consequences. Under intermediation, $\mathrm{C}$ will have no contract or property claim allowing it to reach any of G's assets in particular. In order to collect directly from $\mathrm{D}$, it would first have to win a lawsuit against $G$ for breach of contract and then obtain and enforce a judgment lien against G's interest in D's loan. Such remedies can be costly; more importantly, in the time it takes under state collection law to pursue them, any value remaining in the loan may have dissipated. Furthermore, if $\mathrm{G}$ actually turns out to be insolvent, $\mathrm{C}$ will be forced to participate in bankruptcy proceedings and will have to share any proceeds arising from D's debt (and from G's other remaining assets) with all of G's other creditors on a pro rata basis. ${ }^{83}$

Under a guaranty, in contrast, $\mathrm{C}$ gets an expedited collection procedure and an effective priority in D's debt over G's other creditors, through its option to obtain repayment directly from $\mathrm{D}^{84}$ Of course, giving such an option to $\mathrm{C}$ is not costless; to the ex-

${ }^{81}$ See note 46 and accompanying text.

82 This risk is nontrivial even when dealing with large commercial guarantors and issuers of standby letters of credit, as the 1982 failure of Penn Square Bank illustrated. See Michael A. Goldberg and Peter R. Lloyd-Davies, Standby Letters of Credit: Are Banks Overextending Themselves?, $16 \mathrm{~J}$ Bank Research 28, 30-32 (1985) (noting the problems faced by many beneficiaries of Penn Square Bank standby letters of credit after the bank's collapse).

${ }^{83}$ See 11 USC § 726(b) (1994) (specifying pro rata distribution of property in Chapter 7 liquidations); id § 1123(a)(4) (requiring equal treatment of each claim of a particular class).

"Federal bankruptcy law, however, may limit both of these advantages. See, for example, Trimec, Inc v Zale Corp, 150 Bankr 685, 687 (N D IIl 1993) (applying automatic stay provision of the Bankruptcy Code, 11 USC $\$ 362$ (1988), to defer a creditor's attempt to collect from a nonbankrupt debtor when the debtor shared substantial business identity with a bankrupt guarantor). 
tent that $\mathrm{C}$ is able to satisfy itself out of the proceeds of D's debt to $G$, there will be fewer assets left for G's other creditors. Whether it is efficient to give $\mathrm{C}$ a priority in these proceeds, however, depends on whether that priority is more valuable in C's hands than in the hands of G's other creditors-or equivalently, whether $\mathrm{C}$ gains more from the priority than the other creditors lose.

But a well-established account of how one should allocate priority among creditors in the event of insolvency already exists; it can be found in the economic literature on secured credit. This account begins with the observation that secured credit has higher direct transaction costs than unsecured credit: it is necessary to write a special contract, file a public notice, restrict the use of collateral, and so on. Security is only worthwhile, on this account, if its other advantages justify these costs. This can be the case only if the secured lender places a higher value on a specific interest in the collateral than do the debtor's other creditors; otherwise the cost the debtor will pay when seeking other financing after having encumbered his assets will more than outweigh the benefits he receives in exchange for granting a security interest. ${ }^{85}$ The secured lender's higher value in specific collateral can arise from various factors: from superior information regarding its market or use-value, from a comparative advantage in salvage, from superior ability to monitor the collateral's whereabouts or to prevent it from being diverted to other uses-or from a relatively inferior ability to monitor, evaluate, or make use of the debtor's other assets. If any of these factors are present, value is created when the secured lender takes priority in the collateralized asset, leaving other, unsecured creditors to take their compensation through other property or through an increased price or risk premium. ${ }^{86}$

The advantages and disadvantages of guaranties, when viewed as devices for gaining leverage and priority in the event of default, are precisely analogous. Guaranties have higher direct transaction costs than intermediation. While no public notice is required to create a guaranty, one does need to write a special

\footnotetext{
ss See Schwartz, $18 \mathrm{~J}$ Legal Stud at 210-14 (cited in note 6).

See generally id at 216-18; Scott, 86 Colum L Rev at 925-33 (cited in note 6); Triantis, $21 \mathrm{~J}$ Legal Stud at 249-55 (cited in note 6); Buckley, $72 \mathrm{Va} \mathrm{L} \mathrm{Rev} \mathrm{at} \mathrm{1439-51} \mathrm{(cited} \mathrm{in}$ note 7). In addition, as Ronald Mann has argued, secured credit may also have the advantage of providing a credible commitment against excessive future borrowing by hindering the flexibility of the debtor's business. See Mann, 86 Georgetown L J at 25-26 (cited in note 63); Ronald J. Mann, Explaining the Pattern of Secured Credit, 110 Harv L Rev 625, 649-58 (1997) (arguing that this credible commitment theory provides the best explanation of the empirical evidence relating to the use of security).
} 
contract, keep track of the rights and duties of three parties, and restrict the manner in which the guarantor and creditor deal with the debtor.

Accordingly, guaranties are worthwhile compared to intermediation only if $\mathrm{C}$ places a sufficiently higher value on having a direct claim against $D$ than do G's other creditors; otherwise the costs that $G$ incurs in her dealings with these other creditors will outweigh any benefits she gets when giving or selling the guaranty. This condition will be satisfied if $C$ has superior information regarding the value of D's obligation to $G$, if $C$ has superior ability to supervise D's behavior, or if $\mathrm{C}$ has superior ability to collect from $\mathrm{D}$-in short, if $\mathrm{C}$ has a sufficient comparative advantage over G's other creditors in monitoring or enforcing against $D$.

This condition seems to be satisfied in most cases in which guaranties are used. Because $\mathrm{C}$ generally has had some prior dealings with $\mathrm{D}$, has investigated $\mathrm{D}$, enjoys some special leverage over $\mathrm{D}$, or expects to do any of these things in the future, it makes sense for $\mathrm{C}$ to look directly to $\mathrm{D}$ for repayment or at least to have the option to do so. If $\mathrm{C}$ instead lends to $\mathrm{G}$ on an unsecured basis, it loses all the advantages that flow from its relationship with $\mathrm{D}$. As an illustration, consider the position of an automobile dealer who lends to a college student on a loan cosigned by the student's parent, whose only other liability is a mortgage on the family house. The auto dealer will place a much higher value on the right to proceed against the student than will the parent's mortgage lender, because the latter does not know anything about the student and may not even be accustomed to dealing with cars. Accordingly, the parent will minimize her cost of credit by giving the auto dealer priority over the mortgage lender in whatever value may lie in the student's promise to pay.

Similarly, consider the factoring of consumer accounts. As we saw in the previous subsection, factoring with recourse corresponds to a guaranty in which the consumers take the role of $\mathrm{D}$, the account factor takes the role of $\mathrm{C}$, and the retailer takes the role of $\mathrm{G}$. This arrangement is more efficient than unguaranteed lending because the factor has better access to liquid funds and the retailer has better control over whether the consumers pay their accounts. Factoring is not the only way for the factor to provide liquidity and the retailer to provide monitoring and enforcement; the same result could be achieved through pure intermediation, with the factor making a general unsecured loan to the retailer and the retailer selling on credit to her consumers. But this latter arrangment makes little sense when dealing with a professional factor, for it sacrifices the value of the factor's exper- 
tise relative to other commercial lenders. The reason that a retailer can get more from a factor for her accounts than she can from unsecured creditors is that the factor specializes in lending against accounts and has experience in assessing and monitoring their value. Other lenders such as finance companies and general trade creditors, who know relatively little about accounts or their collection, will only lend against them at an extreme discount. Accordingly, it is most efficient to give the factor a direct right of action against the accounts (and perhaps a security interest in them as well) rather than to ask them to share with these other lenders.

A third example is provided by the typical apartment sublease, where the landlord has little or no role in choosing the subtenant. In this situation, the parties could arrange to have the subtenant primarily liable to the landlord for the rent and the tenant secondarily liable-a guaranty arrangement. Or they could have the subtenant liable only to the tenant, who would in turn be unconditionally liable to the landlord-a form of intermediation. Most likely, however, the parties as a group will be better off having the landlord look for payment from both the original tenant and her subtenant. Beyond the amount of the security deposit, it may be too costly or impossible to collect from a tenant who has moved to another location and taken her personal possessions with her. The value of any payments made by the subtenant, conversely, will likely depend on how well the landlord keeps up its corresponding obligations under the primary lease. Similarly, through its management of the building and adjoining realty, the landlord has superior information regarding the subtenant's activities and whereabouts and so has some control over any misbehavior. This gives the landlord reason to value the subtenant's payments more than the subtenant's other creditors would.

Guaranties are more efficient than pure intermediation, in short, when $\mathrm{C}$ has some special interest or comparative advantage in monitoring $\mathrm{D}$-either relative to $\mathrm{G}$ or to $\mathrm{G}$ 's other creditors. The former comparison will be relevant in the event that $G$ is solvent, and the latter comparison will be relevant in the event that she is not. Intermediation, in contrast, makes sense when the ultimate creditor has no comparative advantage in monitoring or collecting from the ultimate borrower. As a stereotypical example, consider commercial banking as it has traditionally been practiced: the bank obtains liquid funds from various individual depositors and lends them out to various business and consumer borrowers. Here the plainly efficient arrangement is for 
the bank to act as a pure intermediary. Since the depositors are in no position to evaluate or supervise the bank's lending decisions, there is no reason for them to take priority in or to have a direct claim against any particular loan or group of loans. The transaction costs of doing so-including, most importantly, the substantial inconvenience to the depositors of having to concern themselves with the bank's lending portfolio, and the corresponding inconvenience to borrowers of having to deal with inquiries from a multitude of small, scattered creditors-would simply be wasted. ${ }^{87}$

\section{B. Nonefficiency Reasons for Guaranties}

The discussion thus far has focused almost exclusively on considerations of economic efficiency. As the introduction to this Section observed, however, the fact that an exchange yields profits for its participants does not ensure that it is efficient from the social viewpoint, or vice versa. Indeed, many real-world guaranties are motivated in whole or in part by rent seeking-that is, by the prospect of evading regulatory constraints or enjoying distributional gains at the expense of nonparties to the transaction. To complete the analysis, accordingly, and to determine whether any particular guaranty transaction is actually efficient, we also need to survey the ways in which guaranties can impose externalities, avoid private or public regulation, and extract distributional rents.

In the context of commercial credit, the other creditors of $D$ and $G$ are obvious targets for rent extraction. If these creditors are fully aware of the relationship among $C, D$, and $G$, and if the market for credit is competitive, they can fully protect themselves by adjusting the terms of their contracts with $D$ and $G$ to compensate for any resultant changes in risk. Many outside creditors, however, will be unaware of the details of the participants' arrangements (as in the case of incidental trade creditors whose loans are too small to make keeping track of D's and G's doings worthwhile), unable to alter the terms of their loans in response (as is the case with tort claimants and other involuntary creditors), or both (as with employees not represented in collective bargaining arrangements who are creditors to the extent of unpaid wages and benefits). Accordingly, these third parties may

\footnotetext{
${ }^{57}$ For a formal economic model reaching similar conclusions, but focusing on the bank's ability to diversify risk as an explanation of its incentives to monitor effectively, see Douglas W. Diamond, Financial Intermediation and Delegated Monitoring, 51 Rev Econ Stud 393, 398-409 (1984).
} 
suffer negative externalities if the parties to the principal credit transaction are allowed full freedom of contract. ${ }^{88}$

It is difficult, however, to know in which direction these potential externalities cut in the guaranty context. Because (in contrast with secured credit and mortgages) there is no centralized system of notice or recording for guaranties, and because it is difficult for parties not in contact with $D$ to gauge his potential for default, G's other creditors may inadequately adjust for the increased risk the guaranty poses for their claims. This would suggest an incentive for the issuance of too many guaranties. On the other hand, because parties not in contact with G may be unaware of or unable to appreciate the value of her guaranty, D's and C's other creditors are likely to adjust inadequately for the decrease in risk the guaranty provides them. This countervailing factor would imply that too few guaranties are being written.

Conversely, guaranties can impose externalities on debtors with whom $D$ is in competition for funds. To the extent that a guaranty from $G$ allows $D$ to improve his credit prospects by signaling his reliability, part of this informational gain comes at the expense of the general pool of credit applicants. After sending this signal, D appears more reliable than he otherwise would, but others in his risk pool will, as a direct consequence, appear less reliable than they otherwise would. These other applicants, accordingly, will receive less credit on less favorable terms than before. Additionally, to the extent that competing applicants go to the expense and trouble of getting a guaranty of their own, they will find that the more guaranties are provided, the more their signaling value is diluted. In this latter instance, the result may be a rat race in which all parties are worse off than if none had tried to signal in the first place. ${ }^{89}$

\footnotetext{
s This argument should be familiar to followers of the scholarly literature on mortgages and personal property security interests, where it has commonly been offered as a reason to limit the availability of and the priorities arising from secured credit. See, for example, Lynn M. LoPucki, The Unsecured Creditor's Bargain, 80 Va L Rev 1887, 1947-63 (1994); Lucian Ayre Bebchuk and Jesse M. Fried, The Uneasy Case for the Priority of Secured Claims in Bankruptcy, 105 Yale L J 857, 895-903 (1996); Lynn M. LoPucki, The Death of Liability, 106 Yale L J 1, 61-63 (1996). It should be noted, however, that small voluntary creditors stand on a somewhat different footing in this regard than do involuntary creditors. While the former may not know specifically whether their debtors have received or given guaranties, they do know that such guaranties are regularly made, and, if they are sophisticated, they will alter their lending terms to reflect the discounted probability of being exploited (or alternately, benefited) by a guaranty. But since only some debts are guaranteed, this adjustment, while accurate on average, will either be excessive (if no guaranty is given) or inadequate (if a guaranty is in fact given) in the actual case. Accordingly, guaranties still impose externalities on such creditors, even if they are not distributionally disadvantaged in the manner of involuntary creditors.

${ }^{39}$ The classic formulation of this argument can be found in Michael Spence, Job Mar-
} 
Various commonly articulated rationales for guaranties can be understood in terms of such externalities. For instance, it is often claimed that guaranties are preferred for accounting reasons-that they look better on one or more of the parties' balance sheets than would an outright unguaranteed loan. ${ }^{90}$ One reason that guaranties might look better, of course, is that they are in fact more efficient for some of the reasons discussed earlier in this Section; but those who make this claim typically mean that the apparent improvement on paper exceeds the real economic value of the transaction. If they are correct in this regard, it can only be because the accounting and auditing specialists, who supervise the principal parties for the benefit of third-party creditors and investors, use imperfect categories to assess and communicate the parties' financial health. If the combined financial statements of the principals appear spuriously stronger when they use guaranties rather than loans, then third-party creditors and investors will mistakenly be induced to deal with them on more favorable terms than they otherwise would. Similarly, the financial statements of competing actors who do not use guaranties will look weaker in comparison, and such actors will face greater borrowing costs as a result. To the extent that the accounting advantages of guaranties exceed their real economic advantages, the benefit to the principals comes at these third parties' expense. ${ }^{91}$

ket Signaling, 87 Q J Econ 355, 358-61 (1973) (analyzing equilibria in labor markets where employees send costly signals of their quality). See also George Akerlof, The Economics of Caste and of the Rat Race and Other Woeful Tales, 90 Q J Econ 599 (1976) (discussing how signals can upset market equilibria). The proper policy response to such externalities, if they exist, is not obvious. Depending on the particular circumstances, it may be possible to improve social welfare either by subsidizing information acquisition or by taxing it. See, for example, Severin Borenstein, The Economics of Costly Risk Sorting in Competitive Insurance Markets, 9 Intl Rev L \& Econ 25, 32-33 (1989) (demonstrating ambiguity of optimal policy response in insurance setting).

${ }^{90}$ For instance, under current rules of the Financial Accounting Standards Board ("FASB"), banks and other businesses need only disclose standby letters of credit in a footnote to the balance sheet; they do not have to treat the letters explicitly as a contingent liability. See, for example, Medhat Helmi and Nitham Hindi, Raining on Banking's Parade: New Rules Promote Fuller Accounting of Liabilities, 40 Natl Pub Acct 17, 18 (Jan 1995) (arguing that FASB rules should be amended to treat standbys as contingent liabilities, and offering empirical evidence to demonstrate that sufficient data exists to estimate the value of such contingencies). Attempts to correct for the imperfections of such accounting practices are ongoing. For example, under the risk-based capital standards, established in 1988 by the Basle Committee on Banking Regulation and Supervisory Practice and still in the process of implementation through various federal regulations, most domestic banks must include letters of credit when calculating their risk-based capital ratios. See Pawlowic, 23 UCC L J at 416-17 (cited in note 18).

${ }^{91}$ But see Brewer and Koppenhaver, $16 \mathrm{~J}$ Bank \& Fin at 1040-45 (cited in note 71) (presenting empirical evidence that equity markets accurately perceive and price the risk 
Similarly, guaranties can also be driven by tax considerations, because the Internal Revenue Code applies different tax rates to transactions structured as loans or guaranties, even if the transactions are otherwise functionally equivalent. ${ }^{92}$ For instance, a pure multiple-year loan is taxed according to the constant-yield method, which calculates interest as a constant percentage of the net present value of debt owing at any given time. This results in a flow of deductions for $D$ and income receipts for $\mathrm{C}$ that increase steadily over the life of the loan. If the loan is guaranteed, in contrast, a portion of the interest payments are converted into suretyship fees, which are amortized on a straightline basis. The guaranty form thus provides an accelerated pattern of deductions and receipts. ${ }^{93}$ Many such arbitrage opportunities exist in the tax code; for instance, a separate set of rules comes into play if the guaranty is cast in the form of an option. ${ }^{94}$ Any reduction in the parties' combined tax liability from such arbitrage, however, is analogous to an externality imposed on the Treasury and, ultimately, on other taxpayers, in that the parties ignore such costs when deciding how to structure their transaction.

Finally, the parties may cast their relationship in the form of a guaranty in order to evade the substantive constraints of other formal or informal regulations. One straightforward example of such regulation would be the practical constraints imposed by public opinion on U.S. direct government subsidies to foreign governments such as Israel or Mexico. Under current budgetary rules, these subsidies require accompanying tax increases or cuts in other (probably more popular) programs. In contrast, until recently federal loan guaranties to these countries have been treated as off-budget, enabling them better to escape both public and congressional scrutiny..$^{95} \mathrm{~A}$ second example, less straightforward but in its day commercially quite significant, arises from reserve requirements imposed by the Federal Reserve System and the lending limits imposed by the Comptroller of the Currency on federally chartered banks. Under the Fed's requirements, for in-

of standby letter of credit issuance, notwithstanding the limited accounting information currently presented about them).

${ }^{52}$ See generally David S. Miller, Federal Income Tax Consequences of Guaranties: A Comprehensive Framework for Analysis, 48 Tax Law 103, 110-44 (1994).

${ }^{93}$ Id at 111-12.

is at 154-64.

${ }^{95}$ See, for example, Kate Stith, Congress' Power of the Purse, 97 Yale L J 1343, 1379 \& n 176 (1988) (discussing loan guaranties as one of several "backdoor" appropriations mechanisms); Sanford, 28 Geo Wash J Intl L \& Econ at 377-80 (cited in note 25) (discussing the effect of recent budgetary reforms on lending to foreign governments). 
stance, banks must hold a certain percentage of their deposit account liabilities on reserve in the form of cash or deposits in one of the Federal Reserve Banks. ${ }^{96}$ Because Fed deposits earn a lower rate of interest than commercial loans, however, and because cash earns no interest at all, banks have a strong incentive to lend their reserves to the limit. Until the late 1980s, the Fed and the Comptroller did not count guaranty obligations incurred under standby letters of credit against banks' lending limits, on the theory that these obligations were merely contingent. The resulting regulatory loopholes were a major factor in the explosion of standby letters of credit in the 1980s, as banks constrained not to make additional direct loans found that they could increase their effective lending by casting a portion of such loans in the form of guaranties. ${ }^{97}$

Notwithstanding these nonefficiency explanations for guaranties, I have abstracted from them in the preceding discussion for three related reasons. First, an efficiency analysis is interesting in itself and useful to both private and public actors planning transactions. For example, even if we grant that political factors may outweigh efficiency considerations in the packaging of foreign aid, it is still important to know whether it is cheaper to provide such aid in one form rather than another. Second, a clear analytic understanding of guaranties in efficiency terms is necessary before we can address any externalities or regulatory inefficiencies that they may produce. In order to decide how to tax guaranties, for instance, we need to know what guaranties are and how they differ functionally from other transactions for which they are a substitute. Third, the various nonefficiency reasons for guaranties are local and contextual; they vary in detail among industries and regulatory regimes. The basic economic efficiencies underlying guaranties, however, are general and universal. Focusing on what is general rather than on what is contextual allows us to use insights gleaned from one field to inform our understanding of the others.

${ }^{96} 12$ CFR §§ 204.3, 204.9 (1998).

${ }^{97}$ See Barbara Bennett, Off-Balance Sheet Risk in Banking: The Case of Standby Letters of Credit, Fed Res Bank of San Fran Econ Rev 19, $22-23$ (1986) (concluding, however, that real economic demand for guaranties, not capital regulations, was the primary reason for growth in the use of standby credits). The loopholes were largely though not entirely closed by 12 CFR $\S \S 32,208.8 \mathrm{~d}$ (1998), which subjected standby credits, appropriately discounted for risk, to the same lending regulations as ordinary loans. Because the categories for discounting such risk are imperfect, of course, a minor regulatory incentive to substitute standbys for direct loans still remains. 


\section{APPLICATIONS-PUBLIC AND PRIVATE}

The previous Sections of this paper set out a theoretical framework that can unify our understanding of guaranty transactions across a wide variety of legal and policy contexts. This Section shows how that framework can be applied to improve transactional planning. It focuses on two extended examples: the optimal design of government-provided credit assistance, and the liability of commercial issuers of standby letters of credit.

In addition to providing one problem from the public policy arena and one from private commerce, the examples illustrate how the theory can be applied at various stages of planning and levels of detail. The discussion of federal credit policy implicates the broader problem of choosing a basic transactional form-that is, should such credit assistance be provided though guaranties, through direct government lending, or through a program of outright grants and subsidies? To address this broader problem, we will need to apply the analysis of the previous Section at a general level, seeking to identify the party who is the least-cost monitor and enforcer, who has the lowest cost of liquidity, and who places the highest value on a claim against the debtor. Conversely, the example of standby letters of credit implicates the narrower problem of choosing the particular elements of suretyship that should be included in or excluded from a particular transaction, once the basic decision has been made to use the form of a guaranty. To address this latter problem we need to focus on more detailed considerations of comparative advantage: what are the specific risks the transaction is meant to address, what are the particular types of monitoring to be undertaken, and which of the parties is best placed to bear each of these individual obligations? One caveat is appropriate before beginning, however: for both of these examples, the discussion that follows merely sketches the sort of inquiry that is needed to resolve such questions in the context of actual decisionmaking. The point of the exercise is not to reach definitive conclusions, but rather to set out a method by which such conclusions might ultimately be reached.

\section{A. The Government as Guarantor}

Many government policies and expenditure programs are designed with the purpose of assisting individual borrowers; beneficiaries of such programs include farmers, small businesses, students, home buyers, U.S. exporters and their foreign customers, banks, municipalities, and independent sovereign governments. 
The scope and size of these programs, furthermore, are great. By the end of fiscal year 1997, the federal government alone had over $\$ 181$ billion outstanding in direct loans and almost $\$ 822$ billion outstanding in guaranteed loans. When government-sponsored enterprises are added into the mix, the total federal contribution to the credit market exceeded $\$ 2.7$ trillion in 1997 , making the federal government the largest financial institution in the U.S. economy.98

The motives for providing such credit assistance are diverse. They range from redistribution (farm credit, urban enterprise zones) to subsidizing purchases deemed to have some significant public good aspect (home ownership, foreign aid) to correcting some externality or informational failure in the relevant credit market (deposit insurance).$^{99}$ Some policies, such as support for educational borrowing and the much-debated bailout of the Chrysler Corporation in the late 1970s, can be defended (or attacked) on all these grounds.

As we have seen, however, credit assistance can be provided through various means. Most straightforwardly, the state could directly subsidize interest payments, either by outright cash transfers to borrowers or through some sort of tax expenditure. The federal income tax deduction for residential mortgage interest provides the classic example of this first strategy. ${ }^{100}$ Alternatively, the state could itself lend funds to the intended beneficiaries at more generous terms than private creditors would be willing to offer; the National Direct Student Loan program is the model here. ${ }^{101}$ And most indirectly, the state could let beneficiaries borrow on the open market but assume a portion of their risk of default by offering a guaranty, as with the Chrysler and Mexico bailouts. Each of these approaches would lower the beneficiaries' effective price of credit; from the government's perspective, each would entail some expected cost. The payments that would actually need to be made ex post under these three schemes, however, could differ substantially in timing and variance.

In the areas of housing, higher education, foreign aid, and assistance to small business, all three of these approaches have

\footnotetext{
${ }^{93}$ See Analytical Perspectives-Budget of the United States Government, Fiscal Year 1999 165, 186 (OMB 1998).

${ }^{99}$ For a rigorous exposition of the information failure rationale, see N. Gregory Mankiw, The Allocation of Credit and Financial Collapse, 101 Q J Econ 455, 463-69 (1986).

${ }^{100}$ Alternatively, such a tax expenditure could take the form of a tax credit (refundable or otherwise) or of deferral or exclusion of income ultimately produced by the underlying project for which the loan is extended.

${ }^{101}$ See text accompanying notes 10-11.
} 
been tried over the years. More recently, however, there has been a distinct trend away from implementing such programs through direct expenditures and loans and toward implementing them through guaranties. ${ }^{102}$ Obviously, the causes of this trend may have little to do with efficiency and much to do with politics. For a variety of institutional reasons-some statutory, some administrative, some simply political-loans and guaranties have often been easier to enact and implement than direct expenditures. ${ }^{103}$

While it would be unrealistic to ignore such considerations, it is still worth investigating the most cost-effective ways for the government to subsidize borrowing. The choice among these methods remains a live political issue, at least for certain categories of credit. In 1993, for instance, Congress overhauled the federal student loan program, substituting direct lending for guaranties. ${ }^{104}$ While proponents of this policy change largely justified it on grounds of administrative efficiency, critics of the change questioned whether these efficiencies were likely to be realized in practice. ${ }^{105}$ Economic studies have since shown that in fact the net outcome was to increase the costs of the program. ${ }^{106} \mathrm{~A}$ fuller analysis that made use of our conceptual framework could have improved the quality of the debate by helping to clarify the specific costs and benefits of these alternative transactional forms.

\footnotetext{
${ }^{102}$ See, for example, Analytical Perspectives at 185, chart 8-1 (cited in note 98) (indicating that the face value of federally guaranteed loans has increased tenfold from 1970 to 1998, while the face value of federal direct loans has increased only threefold over the same period).

${ }^{103}$ See, for example, Stith, 97 Yale L J at $1379 \mathrm{n} 176$ (cited in note 95); Herman B. Leonard, Checks Unbalanced: The Quiet Side of Public Spending 74-106 (Basic Books 1986) (discussing political appeal of various forms of indirect and off-budget government credit activities, including loans and guaranties); Kate Stith, Rewriting the Fiscal Constitution: The Case of Gramm-Rudman-Hollings, $76 \mathrm{Cal} \mathrm{L} \mathrm{Rev} \mathrm{595,} 608$ (1988) (discussing federal loan guaranties as a "backdoor" appropriation mechanism). Conversely, direct subsidies may have a better chance of enactment if politicians can cast them in the form of tax expenditures, which they can then characterize as tax cuts in election campaigns. See Leonard, Checks Unbalanced at 107-11.

${ }^{104}$ Omnibus Budget Reconciliation Act of 1993, Pub L No 103-66, 107 Stat 312, 342-44 (1993), codified at 20 USC $\$ 1087 \mathrm{c}$ (1994). The changeover was phased in over a five-year period, with the result that 60 percent of federal student loans will be made on a direct rather than a guaranteed basis in fiscal 1998. See Brody, 31 San Diego L Rev at 507 n 223 (cited in note 10).

${ }^{105}$ See Brody, 31 San Diego L Rev at 507-09 (cited in note 10).

${ }^{106}$ See Zimmerman and Miles, 47 Natl Tax $\mathrm{J}$ at 777-82 (cited in note 10); Miles and Zimmerman, 50 Natl Tax $\mathrm{J}$ at $544-48$ (cited in note 10) (finding that the federal government overestimated the budget savings from direct lending because credit risks absorbed by the government were ignored, budget scorekeeping rules pushed recognition of some administrative costs beyond the five-year budget window, and potential increases in administrative costs and government borrowing costs were ignored).
} 
Moreover, recent policy initiatives toward "reinventing government" and rationalizing the budgetary process hold out some hope that the design of future credit assistance programs can be evaluated on the basis of their substantive economic merits. ${ }^{107}$ As the sophistication of financial regulators continues to improve, and as the private sector also develops more accurate methods of accounting for contingent liabilities, ${ }^{108}$ candid evaluations of the comparative transaction costs of alternative government programs should increasingly find an audience.

Accordingly, I will use the framework established in Section II to consider how such programs could best be structured, focusing on the specific examples of higher education, housing purchases, and foreign aid. As the previous Section of this Article demonstrated, the answer to this question turns on two key factors: the comparative costs of liquidity and of monitoring and collecting from debtors. More specifically, if the government has lower liquidity, monitoring, and enforcement costs than do private lenders, then-other things being equal-direct government loans are the most efficient means of assistance. Conversely, if private lenders have lower liquidity, monitoring, and enforcement costs, it is most efficient for the government to subsidize interest payments on private loans directly. Government guaranties are best if the government has a comparative advantage in monitoring and enforcement while private lenders have an advantage in liquidity. Finally, if the government has lower liquidity costs but

\footnotetext{
${ }^{107}$ Under the Federal Credit Reform Act of 1990, for instance, guaranties and other contingent government obligations are no longer automatically treated as off-budget. Federal Credit Reform Act of 1990, Pub L No 101-508, 104 Stat 1388-610, 1388-612-1388-613, codified as amended at 2 USCA $\S 661 \mathrm{c}$ (1997). Instead, the estimated net present value of any new loan or guaranty, taking into account factors such as the interest rate, repayment period, and risk of default, or of any action that alters the terms of existing loans or guaranties, must be reflected in the President's budget and go through the Congressional appropriations process. 104 Stat at 1388-612. Admittedly, the Act does not apply to all federal guaranties, and specifically exempts student loans, veterans' home loans, and other entitlement programs from its coverage. Id. Other loopholes and accounting devices that privilege guaranties over direct expenditures still remain. See, for example, Humphrey, Note, 17 Mich J Intl L at 196-201 (cited in note 24) (describing how the Clinton administration overcame congressional and popular opposition and succeeded in putting together a multilateral aid package of over $\$ 51$ billion, including $\$ 20$ billion in currency swaps and loan guaranties from the U.S. Treasury and Exchange Stabilization Fund); but see Zimmerman and Miles, 47 Natl Tax J at 780 (cited in note 10) (describing how Federal Credit Reform Act budget scorekeeping rules resulted in understating the administrative costs of direct loans, most of which are incurred in years beyond the five-year budget window). Nonetheless, such reforms suggest that there is some political support for closing such loopholes and eliminating such privileges.

${ }^{108}$ See 1991 Report at 9 (cited in note 22) (comparing the government's ability to assess risk with that of the private sector).
} 
higher monitoring and enforcement costs, then the government ought to make the loans but have the private sector guarantee them and bear the risk of default.

Let us then assess these factors in turn, starting with liquidity because those costs are the same across all government credit programs. Does the government have any comparative advantage in liquidity? The answer is unclear. To be sure, the government can borrow at a lower interest rate than private borrowers because its obligations are considered risk-free in debt markets. ${ }^{109}$ In contrast, even a loan to an established bank or blue-chip corporation entails some chance of default. ${ }^{110}$ This risk differential, however, does not reflect a true difference in cost from the social point of view. The main reason that U.S. government bonds are deemed less risky than private bonds is that the government has a clear and credible option that private borrowers who get into financial trouble lack-namely, it has the power to raise funds by levying taxes or printing money.

But these sources of revenue are far from costless. When the government raises taxes, it imposes liquidity costs on the citizens whose tax liabilities are increased and engenders further efficiency costs in the form of deadweight loss or excess burden. ${ }^{111}$ Similarly, when the government prints money, it imposes a real tax on owners of cash and other money balances whose holdings are consequently devalued. Further, an inflationary policy redistributes wealth from creditors whose contracts are denominated in nominal terms to their debtors. Both of these effects lead to

\footnotetext{
${ }^{109}$ Ignoring the risk of inflation, of course. This risk, however, can largely be eliminated by indexing the schedule of payments for inflation or by contracting for a variable interest rate. The U.S. Treasury Department has recently announced a plan to start selling such indexed obligations; roughly equivalent hedges against inflation are widely available on private financial markets. See Jeffrey M. Wrase, Inflation-Indexed Bonds: How Do They Work?, Fed Res Bank Phila Bus Rev 3 (Jul/Aug 1997); David W. Wilcox, The Introduction of Indexed Government Debt in the United States, $12 \mathrm{~J}$ Econ Perspectives 219, 220-21 (1998) (discussing the mechanics of inflation-indexed debt).

${ }^{110}$ While it is theoretically possible that the federal government could someday default on its general obligations, the market judges the chances of this contingency, given political realities, to be minimal. (Recall that during the 1995-96 shutdown of the federal government, both Congress and officials in the executive branch took great pains to assure financial markets that funds would be available without interruption to pay off government bonds as they came due.) The risk of gradual repudiation of such debts through a policy of deliberate inflation is a more serious one; still, this risk is alleviated by the institutional structure of the Federal Reserve, a legally and politically independent agency with discretion over the money supply.

"11 The deadweight loss or excess burden of a tax is the efficiency loss that results when taxes induce taxpayers to substitute away from the taxed activity toward another, relatively cheaper activity - for example, individuals may choose to work fewer hours under a wage tax and save and invest less under a tax on interest income. See, for example, Harvey S. Rosen, Public Finance 31-32 (Irwin 3d ed 1992).
} 
real inefficiencies and the former reduces the liquidity of cashholders. In addition, both levying taxes and printing money can have serious and adverse macroeconomic effects, crowding out investment and worsening the tradeoff between unemployment and inflation. ${ }^{112}$ Properly calculated, then, the government's liquidity costs include all of these potential consequences of increased borrowing, discounted by their respective probabilities and their expected time of occurrence.

As a theoretical matter, if the government always acted with perfect information and rationality, its expected cost of borrowing would have to be lower than that of the private sector. The reason is that the government's option to raise funds via taxes or the printing press-like all options-has a positive expected value. If the option turns out to be less expensive than other sources of liquidity, it can be exercised, while if it turns out to be more expensive, it can be freely ignored. But of course, the government does not always act perfectly when making fiscal or monetary policy. Because of imperfect information, agency problems, the absence of any property rights in the surpluses that could be created by efficient policies, and other costs of administration, the option of tax-based or money-based finance does not necessarily translate into reduced borrowing costs. As Ronald Coase pointed out in a different context, the transaction costs of the government's financial activities are often at least as large as the transaction costs of the private credit market. ${ }^{113}$ As a first approximation, therefore, it is reasonable to treat the government's cost of liquidity, all things considered, as roughly the same as that of private lenders (although I recognize that the question is an empirical one and there is room to disagree).

Turn then to the other half of our inquiry: is there reason to think that the state can engage in monitoring and enforcement more cheaply than private lenders? In the areas of small business lending, student loans, and housing, such a general claim seems problematic. Consider first the component of underwriting and risk assessment. The available evidence suggests that, if anything, government credit standards are weaker than those of the private sector. The government's debt pool is riskier than that of private lenders, and it tends to suffer from disproportionate de-

\footnotetext{
${ }^{112}$ For a more complete discussion of such effects of monetary and fiscal policy, see generally Stanley Fischer, Rudiger Dornbusch, and Richard Schmalensee, Ecoñomics 493558 (McGraw-Hill 2d ed 1988); N. Gregory Mankiw, Macroeconomics (Worth 3d ed 1997).

${ }^{113}$ Ronald H. Coase, The Problem of Social Cost, 3 J L \& Econ 1, 17-18 (1960) (critiquing standard economic theory of market failure and offering transaction cost analysis as the proper alternative).
} 
fault. Some of this risk differential, of course, stems from the adverse selection that comes with being a lender of last resort. But surveys of the government's actual credit practices tend to show that it makes lending decisions based on less information and less sophisticated methods of evaluation than do private lenders. ${ }^{114}$ Indeed, it is hard to see how it could be otherwise. There is no obvious capacity the government has in this regard that private auditors lack. The latter have the advantage of greater experience, more up-to-date information technology, and the incentives for honing their techniques that come from the spur of the profit motive in a competitive market. Furthermore, many of the government's credit assistance programs have been created as entitlement programs, so that both legal authority and the political atmosphere encourage leniency, not efficiency, in applying program criteria.

With regard to supervision of the debtor during the life of the loan and collection following default, the case for governmental comparative advantage is more persuasive, but only marginally so. Certainly the government, through its extensive legal powers and the various carrots and sticks at its disposal, has the capacity to pursue debtors more tenaciously and extract payment more effectively than private creditors; but again, these enforcement devices are not free. Possibly the federal government, as a byproduct of its other record-keeping activities, can more cheaply trace debtors or their assets across state lines-an argument that has frequently been put forward in the context of unpaid child support-but the actual costs of federal investigative and policing resources, as well as the increased time and paperwork required on the part of private citizens in order to comply with government informational requests, would need to be more fully accounted for in considering such a claim. The government's collection costs could also be lower than the private sector, especially if such costs were combined with or offset against other public collection or payment activities. Recent proposals to use the Internal Revenue Service to collect unpaid student loans illustrate this last possibility; similar economies of scope and scale might also be achievable through the welfare or Social Security systems. In this regard, however, it is worth noting that the IRS has generally op-

\footnotetext{
${ }^{114}$ See, for example, 1991 Report at 9, 42 (cited in note 22) (noting that government regulators do not have expertise in risk assessment); U.S. General Accounting Office, High-Risk Series: Guaranteed Student Loans 30-31 (GAO/HR-93-2 1992) ("[T]he inventory of known problems in the [Education] Department's administration of guaranteed student loans raises questions about its ability to adequately manage a direct lending program.").
} 
posed all such proposals to draw on their enforcement resources; ${ }^{115}$ other agencies such as the Social Security Administration (or state drivers' licensing and auto registration bureaus) can be expected to offer similar resistance. The political costs of such policies in terms of reduced civil liberties or individual privacy, in addition, cannot be ignored. While it might be technically possible to use the voter registration or Selective Service systems to identify and pursue recalcitrant debtors, for instance, most people would likely regard the associated risks of abridging fundamental rights as unacceptably high.

In the end, accordingly, the case for public provision of such functions must be made on a more detailed accounting of the relative administrative costs in private and public settings. For some types of collection, such as payroll deductions for loans made to government employees or persons serving in the military, the government may have a real comparative advantage. More generally, however, proponents of bringing credit monitoring services within the government sector should probably be assigned the burden of proof - especially in light of the unwarranted claims of administrative efficiency that they made recently in the area of direct student loans. ${ }^{116}$

There are two specific situations, however, where the government may have a real comparative advantage over private lenders in monitoring and enforcement.

First, the government may have a comparative advantage in contexts where it can affect the financial risk of default of the debtor through other programs. For instance, when the federal government extended the Chrysler guaranties in the late 1970s, it also had several opportunities to revisit its automobile emissions and fuel economy standards, as well as its negotiated policy of voluntary export restraints that effectively placed a quota on the number of Japanese cars sold in the United States. ${ }^{117}$ All

\footnotetext{
${ }^{115}$ See, for example, The Income-Dependant Education Assistance Act, Hearing on HR 2336 before the Subcommittee on Postsecondary Education of the House Committee on Education and Labor, 102d Cong, 2d Sess 67-90 (1992) (statement of Michael S. Bigelow, Deputy Assistant Commissioner, IRS) (outlining the disadvantages to assigning the IRS the responsibility for student loan collection).

${ }^{116}$ See note 10 and accompanying text. Indeed, it is not even clear that the government is the lowest-cost supplier of the collection services it currently provides. See Adam Melita, Note, Much Ado about \$26 Million: Implications of Privatizing the Collection of Delinquent Federal Taxes, 16 Va Tax Rev 699, 705-07, 714-26 (1997) (advocating that federal tax collection be outsourced to private companies, and favorably assessing the results of an IRS pilot program experimenting with such outsourcing).

${ }^{117}$ See Robert B. Reich, Bailout: A Comparative Study in Law and Industrial Structure, 2 Yale J Reg 163, 180-87 (1985) (recounting background to and assessing impact of Chrysler loan guaranties); Michael William Lochmann, The Japanese Voluntary Restraint
} 
these policies had the potential to affect Chrysler's profits significantly by influencing its ability to compete with other auto companies. When the government has the power to influence the risk of a borrower's default in this way, private lenders face a relatively high cost in monitoring and bearing that risk because they cannot predict or control what the government does. Just as a guaranty from a corporate manager or other insider gives the insider incentives to take stronger precautions to ensure the corporation's ability to repay, so would a government guaranty provide the government with more credible incentives to implement riskreducing policies and refrain from risk-increasing ones.

Whether such incentives are actually welfare-enhancing on balance is unclear. The government's potential liability for its guaranties may lead it to take an excessively short-term or narrow financial perspective, distorting its decisions on other policies. Conversely, since public decisionmaking authority is highly decentralized, a guaranty created by one arm of the government may not even be recognized by another arm. Absent supervisory control by an agency like the Office of Management and Budget, the government's ability to respond to incentives created by its guaranties may be no greater than that of a private lender.

Furthermore, this argument threatens to swallow up the entire private market for credit and force the government to stand as a potential guarantor for all debt contracts in the economy; for when the overall effects of fiscal and monetary policy on interest rates and unemployment are taken into account, there is virtually no loan whose risk is not influenced by government action. It is probably best, accordingly, to restrict the use of the argument as a justification for government guaranties to situations, such as the Chrysler case, in which there is an especially significant connection between government actions and the risk of default.

The second situation where government guaranties may be in order is in the foreign policy setting. Here, the government's comparative advantage in monitoring and collection may be quite real. For one thing, the federal government has superior access to information relevant to the risk of default through classified materials, intelligence operations, and confidential diplomatic contacts. While not all this information is available to the particular officials who are charged with making lending decisions, those officials still have better access to it than do private lenders. More

on Automobile Exports: An Abandonment of the Free Trade Principles of the GATT and the Free Market Principles of United States Antitrust Laws, 27 Harv Intl I J 99, 100-09 (1986) (describing and assessing U.S. and Japanese policy toward voluntary export restraints). 
significantly, the U.S. government has more leverage than private lenders do in the event of default. A disappointed private creditor is for most purposes limited to calling in outstanding loans, refusing future extensions of credit, and publicizing the debtor's default. The U.S. government can do all of these, and more. Because of the many dimensions in which nations interact in the international arena, the U.S. has at its disposal a much wider array of foreign policy tools to be used as carrots and sticks-diplomatic concessions, reductions in informal trade barriers, state visits and other gestures of political theatre, the exercise of voting rights in multilateral organizations. As a result, the U.S. government will generally find it easier and cheaper to collect following a default, or to turn the default to its advantage by trading debt forgiveness for other foreign policy concessions it may subsequently find valuable.

As the theoretical framework of the previous Section suggests, whether it is better for the U.S. government to make such loans directly or instead to guarantee loans made by private lenders depends upon whether its advantage in monitoring is partial or complete. Most likely, however, this advantage is partial. While the government possesses some relevant information that private lenders lack, private lenders may conversely possess some information that the government lacks. For instance, such lenders may have greater expertise in project evaluation and risk assessment, especially if the loan is intended for the purposes of economic development or financial reform. The participation of private lenders at the underwriting stage, moreover, also helps to guard against the danger that the government will make an economically unsound loan for unrelated and possibly unwarranted political purposes. For all these reasons, then, the total costs of such a transaction are likely to be minimized by structuring it as a guaranty, as opposed to a direct government loan.

In contrast to these last two situations-domestic loans whose default risks are especially influenced by government policy, and loans to foreign governments-the general efficiency case for government direct loans or government loan guaranties seems weak. If the state has no comparative advantage in either monitoring or liquidity, it should get out of the lending business. This does not mean that the government should not support borrowers; rather, it should do so through direct subsidies such as tax deductions and credits. Indeed, carefully designing such deductions and credits could be a way of targeting them more precisely 
to those most in need. ${ }^{118}$ I suspect that the main reason for the popularity of direct loans and loan guaranties stems not from economic but from political considerations; more precisely, the statutory and procedural constraints of the budgetary process described above make guaranties the cheapest practical way to assist borrowers.

It is worth discussing whether this political preference for guaranties could be justified on second-best efficiency grounds. After all, the constraints of the political process are real constraints; an economist interested in maximizing the sum of benefits over costs should take them into account. Similarly, it might be argued that choosing an inefficient transactional form can be justified on grounds of paternalism. On this argument, if credit assistance is sufficiently worthwhile, an inefficient program of assistance is better than no program at all. If concealing the assistance or disguising its costs by casting it in the form of a guaranty is the only way to get it enacted, such subterfuge is permissible. Something like this seems to have been the rationale of the Clinton administration in fashioning the recent Mexican bailout, and perhaps also was the Bush administration's justification for proposing Israeli loan guaranties some years earlier.

I think, however, that we must conclude that while misrepresenting the costs and benefits of public programs might be justifiable on pragmatic or utilitarian grounds in extreme situations, paternalism of this sort cannot form a basis for government policy in general. Since this Article aims to provide a general method for policy analysis and planning, it must therefore put such considerations aside. Furthermore, it is worth noting that the utilitarian argument for deception by political elites is particularly weak when used in the service of policies (such as the student loan program) that command the support of a broad-based middle-class constituency. Instead, this argument traditionally has been asserted most frequently in the setting of foreign policy, on the grounds that the legislature-and popular opinion-structurally underappreciates the value of expenditures on foreign assistance. But as we have just seen, there is actually a persuasive efficiency case for foreign loan guaranties.

\footnotetext{
${ }^{118}$ The personal income tax provides a particularly flexible set of tools through which to do this; credits or deductions could be limited to borrowers below a certain level of income, could be phased out as the borrower's income rises, or could be deferred over a period of years. See, for example, Brody, 31 San Diego L Rev at 500-07 (cited in note 10) (advocating a system of student loans, administered through the tax system, in which the obligation to repay would be income-contingent).
} 
Finally, even if the government has no comparative advantage in monitoring, liquidity, or enforcement, it is still worth considering whether there is any distributional basis for choosing among guaranties, direct loans, and interest rate subsidies. Indeed, in some cases guaranties may have the advantage of better targeting the benefits of government credit assistance to those borrowers who are deemed most needy or most deserving. ${ }^{119}$ The benefits of interest subsidies are enjoyed by all borrowers regardless of their risk of default. Guaranties and direct low interest loans, in contrast, primarily benefit those borrowers who face high costs in the private credit market. For the same reason, guaranties and direct loans may be better at directing benefits to marginal borrowers who could not otherwise obtain credit, while interest subsidies are paid to marginal and inframarginal borrowers (in other words, those who would be able to obtain credit even without a subsidy) alike. This last advantage is unimportant if the government has a full array of alternative redistributive tools at its disposal, or if it is feasible to restrict interest subsidies to those who could not or would not otherwise borrow. In a second best world where efficiency and distribution must be traded off for one another, however, this advantage cannot be ignored. ${ }^{120}$

\section{B. The Scope of Defenses to Liability Under Standby Letters of Credit}

In recent years, an increasing proportion of commercial guaranties have been created using the specialized device of the standby letter of credit ("SLC"). ${ }^{121}$ The SLC is modelled on the traditional commercial letter of credit ("CLC"), under which a buyer of goods (the applicant) engages a bank (the issuer) to promise to pay the seller (the beneficiary) upon presentation of

\footnotetext{
${ }^{119}$ Thanks to Scott Masten for suggesting this point.

${ }^{120}$ Compare Charles W. Calomiris, Charles M. Kahn, and Stanley D. Longhofer, Housing-Finance Intervention and Private Incentives: Helping Minorities and the Poor, $26 \mathrm{~J}$ Money, Credit \& Bank 634, 647-48 (1994), who show that if loan applications are expensive, rationing subsidies to a random subset of applicants provides a way to provide direct assistance to the most needy. The program provides incentives for those who could obtain credit on their own to self-select out of the program. The authors also observe that delay in processing benefits is a common way that government benefits programs encourage such self-selection.

${ }^{121}$ The dollar value of standby letters of credit issued by U.S. and foreign banks increased from $\$ 51$ billion in 1980 to $\$ 225$ billion in 1986; estimates of the current outstanding volume range between $\$ 400$ and $\$ 500$ billion worldwide and approximately $\$ 250$ billion in the United States alone. See Boris Kozolchyk, The Financial Standby: A Summary Description of Practice and Related Legal Problems, 28 UCC L J 327, 328 \& $n 2$ (1996).
} 
documents showing that the goods have been shipped. ${ }^{122}$ Under an SLC, an applicant $D$ engages an issuing bank $G$ to promise to pay a beneficiary $C$ upon presentation of documents averring that an obligation that $\mathrm{D}$ owes to $\mathrm{C}$ has come due. The main difference between an ordinary guaranty and an SLC, accordingly, is that under the former, $\mathrm{C}$ must show that $\mathrm{D}$ is in default in order to collect from $\mathrm{G}$, while under the latter, $\mathrm{C}$ need only present documents averring that $D$ is in default. But there are also many other important differences between the two, because guaranties are primarily governed by the common law while SLCs are governed by the relatively formalistic law of letters of credit.

The popularity of SLCs stems from three main factors. First, because the parties are permitted to specify whatever documentary conditions they wish, the device is extremely flexible. SLCs are employed in a wide array of modern business transactions, including real estate developments, performance bonds, sales of corporate commercial paper, leases, private placements of securities, and public offerings of municipal debt and other securitized assets. ${ }^{123}$ Second, the administrative costs of processing payment under a letter of credit are relatively low. Under the rules of letter of credit law, a beneficiary C's rights against an issuer G depend only on its compliance with the documentary conditions of the letter under which it seeks payment. The beneficiary does not have to prove the actual fact of default, and the issuer does not have to investigate the substance of the underlying transaction before paying. ${ }^{124}$

Third and perhaps most importantly, using an SLC permits the role of guarantor to be played by a commercial bank. As a

\footnotetext{
${ }^{12}$ Thus, CLCs commonly are referred to as "documentary credits." Documents required under a CLC typically include invoices, packing lists, bills of lading, and the like. For a general description of CLCs, see James J. White and Robert Summers, 3 Uniform Commercial Code § 26-1(a) at 106-08 (West 4th ed 1995); John F. Dolan, Fundamentals of Commercial Activity: A Lawyer's Guide 57-91 (Little, Brown 1991).

${ }^{123}$ See John F. Dolan, The Law of Letters of Credit: Commercial and Standby Credits § 1.06 at 1-34-1-38 (Warren, Gorham \& Lamont $2 d$ ed 1991) (also surveying uses of standby credits to support, inter alia, tax shelters, payment obligations of foreign sovereigns, class-action settlements, interest rate swaps, compliance with arbitral proceedings, and the child visitation rights of a divorced parent residing in a foreign jurisdiction).

124 This central aspect of the letter of credit is part of its legal definition. UCC \& 5102(a)(10) (defining "letter of credit") and § 5-102(a)(6) (defining "document"), provide that letters of credit can condition payment only on the presentation of specified records. Similarly, the Comptroller of the Currency's Interpretive Ruling 7.7016, 12 CFR $\$ 7.7016$ (1994), states: "As a matter of sound banking practice, . . . the bank must not be called upon to determine questions of fact or law at issue between the account party and the beneficiary." But see Kozolchyk, 28 UCC L J at 358 (cited in note 121) (indicating that nondocumentary conditions in actual letters of credit are common, and criticizing such practices as unsound).
} 
general matter, U.S. banks are prohibited by a variety of federal and state regulations from issuing ordinary contractual guaranties; under most traditional interpretations of bank charters, issuing a guaranty would be regarded as an ultra vires (and hence voidable) act. ${ }^{125}$ Traditionally, such restrictions have been justified on the grounds that guaranties do not accord with sound banking practice and pose too great a risk to solvency. ${ }^{126}$ They have also been motivated by independent political goals, such as the populist desire to limit banks' economic power and to prevent them from competing with other financial institutions such as sureties and insurance companies. ${ }^{127}$

These restrictions on bank guaranties, however, have not been interpreted to prevent banks from offering standby letters of credit that are in many respects functionally equivalent to guaranties. In large part this result is an accident of history and of the deliberate exploitation of regulatory loopholes. Commercial banks' authority to issue letters of credit is well established and uncontroversial, going back to the early days of the law merchant. ${ }^{128}$ The law of letters of credit draws no distinction between CLCs and SLCs. ${ }^{129}$ And the specialized nature of the SLC undoubtedly made it difficult for generalist judges and regulators to recognize its potential as a guaranty device.

The fact that historically it has been convenient to cast bank guaranties as SLCs, however, does not imply that the default rules of letter of credit law are well suited to modern guaranty transactions. Indeed, it would be a surprising coincidence if they were, given that SLCs and CLCs arise out of very different sorts of economic exchanges, and that most of the default rules were developed long before SLCs were invented. Accordingly, what I propose here is to use the basic framework of Section II to determine what rules would be most appropriate in the SLC setting. As we will see, the framework suggests that because letter of credit law does not provide beneficiaries of SLCs with good incentives to monitor their debtors or to protect the interests of issuing

\footnotetext{
${ }^{125}$ See Richard A. Lord, The No-Guaranty Rule and the Standby Letter of Credit Controversy, 96 Bank L J 46, 53-58 (1979).

${ }^{126}$ Id at 55-58.

${ }^{127}$ Id at 57. See also Bank of Michigan $v$ Niles, 1 Doug 401, 408-10 (Mich 1844) (holding that a Michigan statute limited the ability of state banks to acquire real estate even for the purpose of conveying it immediately).

${ }^{122}$ See Rufus James Trimble, The Law Merchant and the Letter of Credit, 61 Harv L Rev 981, 981-93 (1948).

${ }^{120}$ In this regard, UCC Article 5 does not even make reference to the term "standby letter of credit," and does not prescribe the particular documents that might serve as a condition for drawing on a letter of credit.
} 
banks, parties entering into SLCs should consider developing contractual provisions that more closely resemble the substantive rights and duties of suretyship law.

1. Guaranties versus letters of credit: The independence principle.

Before we begin the analysis, a brief digression into the letter of credit literature is in order, since viewing SLCs through the lens of guaranties will strike many specialists in the field as anathema. In the orthodox view, the letter of credit's documentary nature, which formally separates it from the underlying transaction for which it serves as security, is deemed critical to its commercial utility. Indeed, this feature of the letter of credit is considered so important that it has been reified and given a special name: the "independence principle."130 According to this principle, keeping the issuer's obligation to the beneficiary independent from the underlying transaction-and from any claims the issuer or the applicant might have against the beneficiary arising out of that transaction-is essential to keeping the costs of a letter of credit low and its market value high. ${ }^{131}$ Thus, most prominent commentators on letters of credit stress that while the standby letter might serve some of the economic functions of a guaranty, it is not a guaranty, it is not a type of guaranty, it is a grave analytic error to call it a guaranty, and most important of all, it is not subject to the law of suretyship. ${ }^{132}$

Such admonitions, though expressed in the language of formal legal doctrine, must of course be understood in functional terms. If it were a defense to issuer liability that the beneficiary had breached some substantive duty toward the applicant-such as shipping nonconforming goods or failing to provide promised security for its own performance-it would no longer be possible to judge letters of credit on their face. Instead, creditors would need to discount the value of a letter of credit by the possibility that a substantive dispute would develop or be manufactured be-

\footnotetext{
${ }^{130}$ See Alces, 1993 U Ill Rev at 450-52 (cited in note 38); Harfield, 26 UCC L J at 196 n 2 (cited in note 18); Trimble, 61 Harv L Rev at 1006 (cited in note 128).

${ }^{131}$ The drafters of the newly revised Article 5 took pains to make this point with special clarity. As that article's Prefatory Note states: "Revised Article 5 clearly and forcefully states the independence of the letter of credit obligations from the underlying transactions that was unexpressed in, but was a fundamental predicate for, the original Article 5. (Sections 5-103(d) and 5-108(f)). Certainty of payment, independent of other claims, setoffs or other causes of action, is a core element of the commercial utility of letters of credit." Prefatory Note, UCC $\$ 5$ ("Benefits of Revised Article 5 in General").

${ }^{132}$ See, for example, White and Summers, 3 Uniform Commercial Code $\$ 26-2$ at $112-$ 18 (cited in note 122); Harfield, 26 UCC L J at 203 (cited in note 18).
} 
fore drawing. This risk would not only increase the costs of processing and paying letters of credit; it would also substantially reduce the beneficiary's certainty of receiving payment. ${ }^{133}$

In the traditional view of most commentators, applying the common law of suretyship to SLCs would undercut their reliability in two ways. First, as we have seen, suretyship law typically allows guarantors to raise a broad variety of substantive defenses to liability, including both the claims of the primary obligor and the special suretyship defenses based on creditor actions that increase the risk of default. While it is possible to contract out of these defenses-for example, by having the guarantor waive them in advance-such arrangements are often disfavored by courts and regulators. ${ }^{134}$ Furthermore, even when such waivers are enforceable, arranging for them adds to the cost of the transaction.

Second, as a branch of the common law, suretyship law incorporates a variety of equitable and quasi-equitable principles such as reasonableness, due care, waiver, estoppel, substantial performance, and the like. These doctrines make suretyship law much less rule-oriented, much more subject to judicial expansion in the face of sympathetic facts, and hence much less predictable to commercial specialists than letter of credit law. Because such specialists and their clients are repeat players in the guaranty game, they place high value on knowing their exact rights and duties and avoiding interpretative disputes. From their perspective, general common law principles are not appropriate in the letter of credit field because they would disrupt a clear and wellfunctioning set of specialized usages and commercial practices.

For these reasons, representatives of issuer and beneficiary interests fought hard-and for the most part successfully-to keep letters of credit outside the scope of the new Restatement of Suretyship and Guaranty. As a result of their efforts, Section 4(2) of the Restatement explicitly excludes obligations governed by the law of letters of credit. ${ }^{135}$ To the same end, the new 1995 revi-

\footnotetext{
${ }^{129}$ But see the standard argument in the field of negotiable instruments over protecting the holder in due course, as outlined in White and Summers, 2 Uniform Commercial Code $\$ 17-1$ at 149-51 (cited in note 122).

${ }^{13}$ See Alces, 61 NC L Rev at 660-76 (cited in note 49); LoPucki, et al, Commercial Transactions at 514-19 (cited in note 46).

${ }^{135}$ See Restatement 3d $\$ 4$ comment c (cited in note 5) ("The reason for this exclusion is practical. The law governing letters of credit is quite well developed, and is generally understood to govern all letters of credit, both traditional and standby. No good purpose would be served by disturbing that state of affairs."). For an insider's account of the politics of drafting the Restatement, see Rapson, 34 Wm \& Mary L Rev at 991-93 (cited in note 2); for an analogous account of the Article 5 revision process, see James J. White, The
} 
sion of Article 5 goes out of its way to stress that letters of credit constitute a distinct commercial specialty not governed by ordinary principles of contract or suretyship. ${ }^{136}$ The revision also introduces several innovations that are plainly intended to further formalize the parties' rights and duties and to discourage interpretative disputes. ${ }^{137}$

Notwithstanding this doctrinal compromise, however, some commentators continue to maintain that it was a mistake to treat SLCs and guaranties as conceptually distinct transactions subject to wholly separate theories of liability. Peter Alces, for instance, has argued that the difference between the two is merely a matter of degree and that, accordingly, the compromise that excluded SLCs from the scope of the new Restatement was unprincipled and unjustified. ${ }^{138}$ As he points out, because SLCs remain subject to the defense of material fraud, and because the parties are always free to specify documentary conditions that depend on underlying substance, it is incorrect to view SLCs as entirely independent of the substantive transactions they support. ${ }^{139}$

To these arguments we may add the observation that even if the status of the underlying transaction is irrelevant to the issuer's immediate duty to honor a standby letter of credit, the transaction's status is still quite relevant to determining whether the beneficiary is ultimately entitled to retain payments received under that letter. Even under revised Article 5, a beneficiary C who draws on a letter of credit impliedly warrants to the issuer G that no material fraud or forgery has taken place and to the applicant $\mathrm{D}$ that the drawing does not violate the underlying agreement between $\mathrm{C}$ and $\mathrm{D} .{ }^{140}$ For instance, if the underlying contract authorizes the beneficiary to draw on the letter of credit only upon the applicant's default, a beneficiary who drew in the

Influence of International Practice on the Revision of Article 5 of the UCC, $6 \mathrm{Nw} \mathrm{J}$ Intl L \& Bus 189, 194-208 (1995) (describing the influence of the ICC's Uniform Customs and Practice on the revision of Article 5 of the UCC).

${ }^{136}$ See UCC § 5-103 comment 1 (justifying the distinction between guaranties and letters of credit in terms of the independence principle and the need for certainty and speed of payment).

${ }^{137}$ These changes include: defining good faith as mere "honesty in fact," UCC \& 5102(a)(7), in contrast to the more equitable standard of "reasonable commercial standards of fair dealing" found in Section 2-103(1)(b) (substituting a strict compliance principle, UCC § 5-108(a), for the doctrines of waiver and estoppel that would otherwise apply under Section 1-103; eliminating consequential damages and, more strikingly, the duty to mitigate damages, UCC \$ 5-111(a); and providing that courts must award attorneys' fees to the prevailing party in any dispute that arises over the issuer's duty to pay, UCC \& 5111(e)).

${ }^{138}$ See Alces, 1993 U III L Rev at 479-82 (cited in note 38).

${ }^{139}$ Id at 472-74.

${ }^{140}$ Compare revised UCC $\$ 5-110(a)$ with previous UCC $\$$ 5-111 (ALI 1994). 
absence of default (or in the mistaken belief that there had been a default) would be obligated to return any funds wrongfully obtained and to make the applicant whole for any losses that had forseeably resulted from the wrongful draw. Similarly, if a standby letter of credit required $\mathrm{C}$ to present a sworn affidavit that it had exercised its best efforts to collect from $D$ or to levy on his collateral, and it knowingly and falsely so swore, G would be entitled to the return of any funds advanced on the basis of the false affidavit. Thus, while the letter of credit places the burden of inertia on $D$ in the event of a substantive dispute, and while it may force $\mathrm{G}$ and $\mathrm{D}$ to pursue $\mathrm{C}$ in a distant and inconvenient location, it does not insulate $\mathrm{C}$ from the obligation to comply with its substantive contractual duties.

To restate the point in somewhat stronger terms, the main differences between standby letters of credit and guaranties are not substantive, but procedural. The choice between the two forms does determine who bears the burden of bringing suit on the underlying claim, and it may affect the forum in which that suit can be litigated, but these are only two of many factors the parties care about. Whether payment precedes performance is an important term in all contracts, and so is the forum where disputes may be heard, but these facts do not diminish the importance of the other aspects of the deal. From the viewpoint of parties allocating risk, liquidity costs, and monitoring and enforcement duties, accordingly, guaranties and SLCs are analogous in many respects. ${ }^{141}$

\section{The efficient design of standby letters of credit.}

With all this as background, we may now ask: what bearing does the economic framework laid out in Section II have on this debate? What implications does it suggest for the possible conditions that might be put on the liability of letter of credit issuers?

First of all, it suggests that the independence principle sacred to letter of credit specialists is ultimately just a shibboleth.

\footnotetext{
${ }^{141}$ Indeed, the drafters of revised Article 5 conceded the analogy in their treatment of the specific question of whether an issuer who extends funds should be subrogated to the beneficiary's rights against the applicant. Revised Section 5-117 provides that an issuer who honors a beneficiary's presentation, and an applicant who reimburses his issuer, will be subrogated to the same extent that they would be under suretyship law. See UCC § 5117 comment 1 (specifically referencing the Restatement 3d). Prior case law, while not unanimous on the point, tended to deny subrogation on the grounds that denial was necessary to maintain the formal distinction between letters of credit and guaranties. See generally Amelia H. Boss, Suretyship and Letters of Credit: Subrogation Revisited, $34 \mathrm{Wm}$ \& Mary L Rev 1087, 1097-1127 (1993) (examining and criticizing the case law and defending the approach of revised Article 5).
} 
While it might well be appropriate to limit issuers' defenses to liability-just as it is sometimes appropriate to limit or waive guarantors' defenses under suretyship law-any substantive difference between standby letters of credit and conventional guaranties ought to turn on functional differences in the nature of the risks being allocated and on the particular monitoring, liquidity, and enforcement obligations assigned to the various participants, not on abstract formalisms. Furthermore, while there do exist some functional differences between guaranties and SLCs, those differences are less significant than the differences between SLCs and traditional CLCs, which current law treats identically.

More specifically, the typical configuration of monitoring, enforcement, and liquidity costs under a standby letter of credit is closer to that of an ordinary guaranty than to that of a traditional CLC. This is true for two major reasons. First, as we have seen, letter of credit specialists regard the administrative costs of processing payment as the primary determinant of a letter's commercial value. ${ }^{142}$ This view makes good sense in the case of a traditional CLC, where the issuer expects to make payment under the letter in ordinary course. With a standby letter of credit, however, the parties' usual expectation is that the applicant will make good on his underlying obligation and the letter will never need to be honored. While the specialists acknowledge this distinction (and, often, draw attention to it), most of them fail to recognize its main economic implication-that the expected costs of payment, discounted for probability, make up a much smaller fraction of the issuer's total costs under an SLC than under a CLC. For SLCs, payment costs are dwarfed by the expected costs of investigation, underwriting, monitoring, and collection, and are thus far less important to the standby letter's commercial value.

Second, and conversely, in the event that an SLC is drawn on, there is a much higher chance that the applicant will be uncollectible or unwilling to pay than under a CLC. ${ }^{143}$ After all, CLCs are intended to facilitate payment in an ongoing deal, while SLCs are intended only as a backup form of payment in case a credit transaction goes bad. While CLC applicants often pay cash up front, prepayment is not feasible for an SLC applicant, since the whole point of the transaction is to provide him with liquid credit. Furthermore, because of the sorts of transactions in which

\footnotetext{
${ }^{142}$ See, for example, Dolan, The Law of Letters of Credit $\$ 3.07$ at 3-25-3-36 (cited in note 123); Kozolchyk, 28 UCC L J at 334-35, 358-59 (cited in note 121); Boss, 34 Wm \& Mary L Rev at 1092-94 (cited in note 141); UCC § 5-103 comment 1.

${ }_{143}$ See White and Summers, 3 Uniform Commercial Code $\$ 26-1$ at 110 (cited in note 122); Dolan, The Law of Letters of Credit $\$ 1.04$ at 1-15-1-18 (cited in note 123).
} 
they are used, SLCs contain different terms and payment conditions from traditional CLCs; one recent survey showed that SLCs involve higher fees, cover larger loans, have fewer restrictions on transfer, and provide for a much longer expiration period. ${ }^{144}$ For all these reasons, the beneficiary's incentives to monitor and to take precautions against the applicant's default are much more important for SLCs than for CLCs.

Admittedly, in some standby transactions the beneficiary's ability to supervise the applicant is very limited, as in asset securitization arrangements in which an SLC allows mortgage- or municipal bond-backed securities to be marketed to small and distant investors. ${ }^{145}$ For many other SLCs, however, the beneficiary may well be in a position to do some part of the monitoring or enforcement. For example, while a bank may have a comparative advantage in assessing its customer's overall creditworthiness and collecting from him in the event he defaults, it may not be the best underwriter with regard to the line of business in which he now proposes to invest. The bank may well lower the total expected costs of the underlying loan by assigning at least some investigation and monitoring tasks to the beneficiary $\mathrm{C}$, and by backing up that assignment with some legal consequences if those tasks are mishandled.

The default rules and understandings of traditional letter of credit law, however, are motivated by the needs of the traditional CLC transaction, and do not provide beneficiaries of SLCs with good incentives to monitor or collect from the applicant. Under a traditional CLC, let us recall, the main task of the beneficiary is to ship conforming goods, not to monitor the applicant's ability to pay or keep track of his assets. The beneficiary's main incentives to ship such goods, furthermore, do not come from the promises or warranties it makes to the issuing bank. Material fraud in the transaction is difficult to prove and the issuer likely will prefer to look to the applicant for reimbursement. Rather, the beneficiary's incentives come from the fact that if it does not present shipment documents, such as bills of lading or inspection certificates, it will not be paid, and that if the goods are defective it will be liable to the applicant for breach of the underlying contract, subjecting it to damages in its home forum. A breaching seller, furthermore, is also likely to forfeit future business from the applicant and possibly from his business acquaintances.

\footnotetext{
${ }^{14}$ See Kozolchyk, 28 UCC L J at 329 n 3, 334 (cited in note 121) (reporting author's survey of practices at six major national banks).

${ }^{145}$ Id at 338-54 (describing a typical municipal bond transaction in detail).
} 
Under a standard SLC, in contrast, all these enforcement devices are weakened. While the typical documents required to obtain payment under a CLC provide independent evidence that the beneficiary has performed its shipment obligation, the analogous documents required under an SLC typically do not show that the beneficiary has performed any monitoring or collection obligations. The insolvency or default of the applicant $D$ reduces the chance that it will pursue its legal rights against the beneficiary $\mathrm{C}$ in a distant forum; it also largely eliminates the factor of future business. Furthermore, the benefit of C's monitoring and enforcement efforts accrue to the issuer $G$, not to the applicant $D$; and $\mathrm{G}$ has very limited rights against $\mathrm{C}$ under the default rules of Article 5. At most, $\mathrm{C}$ is obligated not to engage in outright fraud and not to present materially false or forged documents when drawing on the letter. If $\mathrm{D}$ has defaulted due to $\mathrm{C}$ 's negligence, $\mathrm{G}$ has no recourse.

Based on the foregoing analysis, therefore, I tentatively conclude that Article 5's default provisions regarding liability, defenses, and risk allocation are not optimally suited to the standard SLC transaction. Such a conclusion should not be regarded as especially surprising, given that the default rules of letter of credit law evolved well before SLCs were invented, and that the transactions governed by SLCs have been cast in that form in large part to evade regulatory restrictions that, while possibly justifiable in their original historical context, are in modern financial markets increasingly obsolete. ${ }^{146}$ If SLCs were being designed from scratch today, they might well be structured as ordinary guaranties and thus be governed by the default rules of the Restatement. ${ }^{147}$

This conclusion does not necessarily imply, pace Professor Alces, that Article 5 needs to be amended or that all standby letters of credit should have been made subject to the new Restatement. Many of Article 5's rules are default rules, after all, subject

\footnotetext{
${ }^{166}$ See generally Daniel R. Fischel, Andrew M. Rosenfield, and Robert S. Stillman, The Regulation of Banks and Bank Holding Companies, 73 Va L Rev 301, 301-04 (1987) (describing and defending various forms of financial deregulation that occured in the 1980s, including the lifting of traditional restrictions on branch banking, the payment of interest on demand deposits, and bank entry into the credit card business). See also notes 90 and 107 (describing accounting innovations implemented under the auspices of the Federal Credit Reform Act, Federal Reserve, Comptroller of the Currency, Basle Committee on Banking Regulation and Supervisory Practice, and FASB).

${ }^{147}$ Although to the extent that a document labeled as an SLC includes significant nondocumentary conditions precedent to payment, it is already governed by the Restatement, notwithstanding the intentions of its drafters. See revised UCC \& 5-102 comment 6 (stating that such conditions render the document in question something other than a letter of credit, thus excluding it from the coverage of Article 5).
} 
to change by the contracting parties if they choose. The process for amending the UCC is cumbersome and, as a practical matter, requires the substantial assent of the main interest groups affected. ${ }^{148}$ Furthermore, the preference of letter of credit specialists for rules over standards and for well-established trade usages over contextual common law principles is wholly legitimate.

The conclusion does suggest, however, that individual parties transacting under Article 5 should give serious thought to developing contractual provisions and documentary conditions that more closely resemble the substantive risk allocations and monitoring duties provided under the Restatement for standard guaranties. For instance, parties drafting loan contracts supported by an SLC might consider including a covenant in their underlying contract stating that the issuer $\mathrm{G}$ is to be considered a third-party beneficiary of any promises made in the contract by the lender $\mathrm{C}$ to the borrower D. Such a clause would allow G to assert D's claims against $\mathrm{C}$ for breach of the underlying deal, even though $\mathrm{G}$ could not independently assert any such claim under the letter of credit. Similarly, a bank drafting a standby letter of credit might consider including among its documentary conditions a requirement that the beneficiary $C$ present a certified judgment of an independently selected arbitrator that the applicant $\mathrm{D}$ is actually in default or, alternatively, that $\mathrm{C}$ present a sworn and signed affidavit stating that it has undertaken all commercially reasonable efforts to monitor $\mathrm{D}$ and to maintain all rights against collateral during the period leading up to default. Or, the bank might require affidavits with respect to underwriting and credit investigation before issuing the standby letter in the first place.

Parties who attempt to draft such arrangements, of course, may ultimately decide that the arrangements are not worth bothering with, or may discover that beneficiaries are unwilling to agree to them. But such an outcome should result only if the costs such arrangements impose on beneficiaries exceed the savings they create for applicants and issuers. If the beneficiaries of SLCs do indeed have a comparative advantage in some aspects of monitoring, they should be more than willing to accept such provisions in exchange for changes in other terms of the bargain that benefit them-such as an increase in the interest rate they receive for lending funds.

Such provisions and conditions should not be seen as objectionable by bank regulators motivated by the public interest, be-

\footnotetext{
${ }^{148}$ See generally Alan Schwartz and Robert E. Scott, The Political Economy of Private Legislatures, 143 U Pa L Rev 595, 601-02 (1995).
} 
cause they would generally operate to reduce issuers' risk rather than to increase it. In this regard, it is ironic-if not a classic example of how regulation can lead to perverse results-that banks originally began writing SLCs in order to evade prohibitions on their issuance of guaranties. To the extent that the beneficiaries of SLCs undertake duties of care to issuers, and to the extent that issuers can enforce duties owed by beneficiaries to applicants, bank solvency will only be strengthened. The only potential losers would be the inefficient competitors who benefit by keeping banks out of the guaranty business, and who would therefore lose from free and open competition.

\section{CONCLUSION}

This Article has identified the basic economic logic underlying the standard guaranty transaction, showing that a short and simple list of principles can explain the structure and purpose of such transactions across a wide variety of legal and policy contexts. To recapitulate, supplying credit entails various costs, including monitoring costs (defined here to include such things as investigation, risk-assessment and underwriting, and auditing), enforcement costs (including collection, pursuit of legal process, salvage, resale, and allowances for bad debt), liquidity costs, miscellaneous administrative costs, and the time value of money. In an ordinary direct loan, the creditor incurs all these costs and charges the debtor for them in the form of interest. A guaranty, in contrast, provides a way for a lender to unbundle some of the risks of the debtor's default - together with associated monitoring and enforcement obligations-and sell them to another party, the guarantor. Such an arrangement makes sense if and only if the guarantor has a comparative advantage in monitoring or enforcement and the original lender has a comparative advantage in liquidity. Otherwise, it will be cheaper and more efficient for either party-creditor or guarantor-to lend on an unconditional basis. In cases where these conditions are met, however-or, more precisely, where the advantages of specialization are large enough to warrant incurring the additional transaction costs of writing and enforcing a three-corner arrangement-such unbundling can lower the total costs of making the loan, thereby creating a transactional surplus that can be shared among all three participants.

This Article has also identified the conditions where guaranties are superior, as measured by the criterion of economic efficiency, to alternative three-party transactions such as straight intermediation. The distinctive feature of a guaranty relative to 
intermediation is that the creditor buys an option to collect directly from the debtor, instead of collecting from the guarantor and having her collect from the debtor. Granting the creditor such an option is efficient when, and only when, the creditor holds a comparative advantage in some aspect of monitoring or enforcement relative to the guarantor or to the guarantor's other creditors. Otherwise, the option will be more valuable remaining in the guarantor's hands.

This analytic framework helps us to integrate and synthesize a disparate body of knowledge from multiple fields of legal and commercial practice-including, among other things, personal property security, mortgages, negotiable instruments, corporations, letters of credit, the law of contract assignment and delegation, government contracts, and federal expenditure programs aimed at encouraging the greater availability of credit. In so doing, the framework allows us to use insights from one field to critique and improve transactional planning in others. In Section III, for instance, our framework implied that government loans and guaranties are inefficient unless the government has some comparative advantage in monitoring debtors. It also showed that the default rules provided by UCC Article 5 probably do not provide an optimal mix of rights and duties in the context of standby letters of credit.

In addition, though we did not focus on the possibility here, the framework could be used to help clarify ambiguous transactions for the purposes of other social policies or legal doctrines. As just one illustration, under the common law Statute of Frauds, courts have often struggled over whether to treat a given transaction as a suretyship, which is subject to the formal requirement of a signed writing, or to treat the transaction as a primary obligation of the putative guarantor, enforceable even when oral. ${ }^{149}$ The framework in this Article suggests a possible answer to this problem. As we have seen, the functional essence of a guaranty is that the creditor $\mathrm{C}$ (and the guarantor $\mathrm{G}$ ) has some comparative advantage in monitoring or collecting from the debtor $\mathrm{D}$, and thus retains the obligation and incentive, legal or practical, to engage in such monitoring or enforcement. Conversely, if $\mathrm{C}$ cannot plausibly be assigned any type of monitoring or enforcement obligation, the transaction is not properly a guaranty from the economic

\footnotetext{
${ }^{119} \mathrm{On}$ this distinction, see examples provided in Charles $\mathrm{K}$. Burdick, Suretyship and the Statute of Frauds, 20 Colum L Rev 153, 153-56 (1920); John D. Calamari, The Suretyship Statute of Frauds, 27 Fordham L Rev 332 (1958); 72 Am Jur 2d Statute of Frauds $\S 180$ (1974) ("Tests as to Nature of Undertaking"). Thanks to Allan Axelrod for suggesting this application.
} 
viewpoint, notwithstanding any decision by the parties to denominate the contract as a guaranty or to formally preserve C's right to proceed against $D$. This economic distinction, furthermore, accords with the functional purposes of requiring guaranties but not intermediation agreements to be put into writing. Once an intermediary G knows that she is the only person with the capacity or incentive to engage in monitoring the debtor, she is likely to take the prospect of responsibility for his default very seriously. If $\mathrm{G}$ assumes that the ultimate creditor $\mathrm{C}$ will undertake a significant portion of the risk and the associated monitoring, however, she may enter into the transaction with much less forethought. Requiring a writing in this latter case, accordingly, promotes the overall cautionary, evidentiary, and channeling purposes of the Statute. ${ }^{150}$

Other extensions and potential applications of the framework abound, for the basic principles of the guaranty contract touch virtually every field of commerce and industry. The factors that influence whether a guaranty is efficient, for instance, are analogous to those that arise when analyzing problems of reinsurance, financial options, trusts, and asset securitization. Similarly, the incentive properties of suretyship are akin to those provided by the doctrines of fraudulent conveyance law; indeed, with only a small stretch the duties imposed on transferees by such doctrines could be reconceived as those of a guarantor. And as the discussion in Section II.A.4.b made clear, the economic structure of guaranty relationships is analogous to that of secured credit. In this last regard, it is also noteworthy that guaranties and security interests are commonly used in tandem. In subsequent research, it would be worth exploring the close connection between these two devices and the extent to which they may operate as substitutes or complements in particular instances.

Furthermore, this Article has focused almost entirely on the problem of minimizing transaction costs for the three parties to the potential guaranty. As the concluding discussion to Section II indicated, however, guaranties can impose significant external costs on competing creditors and debtors. Now that the basic economics of the guaranty transaction have been laid out, an obvious next step would be to consider how such third-party externalities could best be addressed and internalized. Possibilities in this re-

\footnotetext{
${ }^{150}$ See Arthur T. Von Mehren, Civil-Law Analogues to Consideration: An Exercise in Comparative Analysis, 72 Harv L Rev 1009, 1016-17 (1959) (discussing evidentiary, cautionary, channeling, and deterrent functions of the common law consideration doctrine).
} 
gard might include improved accounting standards, stronger financial disclosure requirements, or a centralized filing system for guaranties on the model of the one currently provided for security interests under Article 9 of the UCC.

In short, the importance of the guaranty contract in law and commerce is vast-so vast, in fact, that it is remarkable that its incentive structure apparently has never been investigated using the tools of the economic analysis of law. The actual amount of economics needed for the task, furthermore, is not especially complicated. Once one asks the basic question-why a guaranty?-and draws the connections between the various contexts in which the guaranty relationship arises, the rest of the analysis follows in fairly straightforward fashion. The primary contribution of this Article, accordingly, is to have asked the question and drawn the connections. 